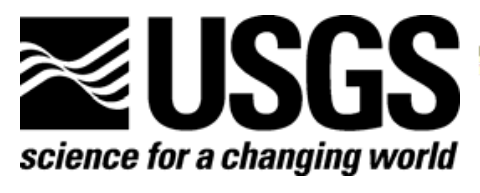

In Cooperation with the National Park Service

\title{
Coastal Change-Potential Assessment of Sleeping Bear Dunes, Indiana Dunes, and Apostle Islands National Lakeshores to Lake-Level Changes
}

By Elizabeth A. Pendleton, E. Robert Thieler, and S. Jeffress Williams

U.S. Geological Survey 2005-1249

U.S. Department of the Interior U.S. Geological Survey 


\section{U.S. Department of the Interior DIRK KEMPTHORNE, Secretary}

\section{U.S. Geological Survey \\ Mark D. Myers, Director}

U.S. Geological Survey, Reston, Virginia 2007

For product and ordering information:

World Wide Web: http://www.usgs.gov/pubprod

Telephone: 1-888-ASK-USGS

For more information on the USGS - the Federal source for science about the Earth, its natural and living resources, natural hazards, and the environment:

World Wide Web: http://www.usgs.gov

Telephone: 1-888-ASK-USGS

Suggested citation:

Pendleton, E.A., Thieler, E.R. and Williams, S.J., 2007, Coastal change-potential assessment of Sleeping

Bear Dunes, Indiana Dunes, and Apostle Islands National Lakeshores to lake-level changes: U.S.

Geological Survey Open-File Report 2005-1249, Web Only.

Any use of trade, product, or firm names is for descriptive purposes only and does not imply endorsement by the U.S. Government.

Although this report is in the public domain, permission must be secured from the individual copyright owners to reproduce any copyrighted material contained within this report.

For Additional Information:

See the National Park Unit Coastal Vulnerability study at http://woodshole.er.usgs.gov/project-pages/npscvi/, the National Coastal Vulnerability study at http://woodshole.er.usgs.gov/project-pages/cvi/, or view the USGS online fact sheet for this project in PDF format at http://pubs.usgs.gov/fs/fs095-02/. Great Lakes National Lakeshores Web pages are at http://www.nps.gov/slbe/, http://www.nps.gov/apis, http://www.nps.gov/indu.

Contact:

http://woodshole.er.usgs.gov/project-pages/nps-cvi/ Telephone: 508-548-8700

Rebecca Beavers

National Park Service

Natural Resource Program Center

Geologic Resources Division

P.0. Box 25287

Denver, CO 80225-0287

Rebecca_Beavers@nps.gov

Telephone: 303-987-6945 


\section{Contents}

Coastal Change-Potential Assessment of Sleeping Bear Dunes, Indiana Dunes, and Apostle Islands National Lakeshores to Lake-Level Changes ………………......................................................................

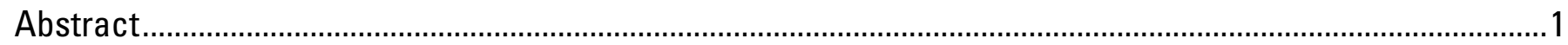

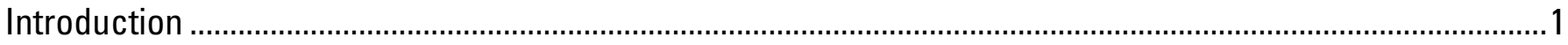

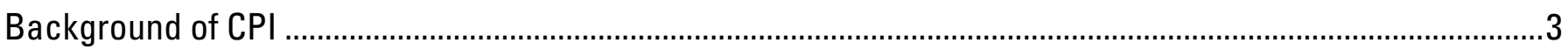

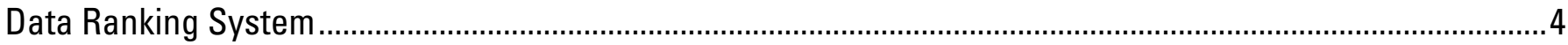

The Great Lakes National Lakeshores......................................................................................................

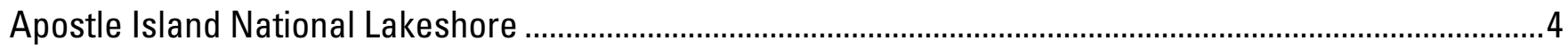

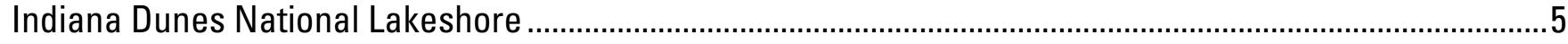

Sleeping Bear Dunes National Lakeshore ..............................................................................................

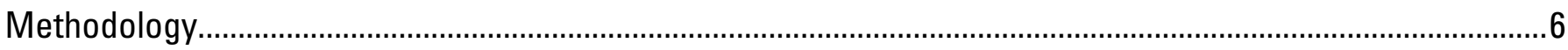

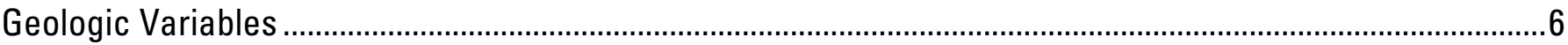

Physical Process Variables ....................................................................................................................

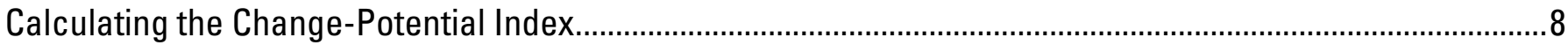

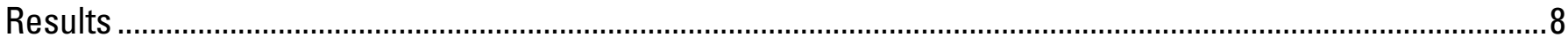

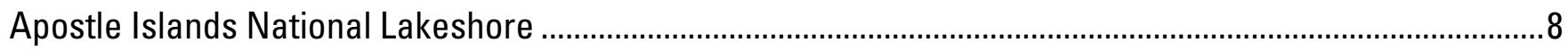

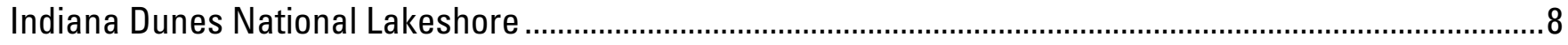

Sleeping Bear Dunes National Lakeshore .................................................................................................

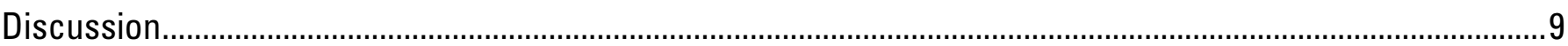

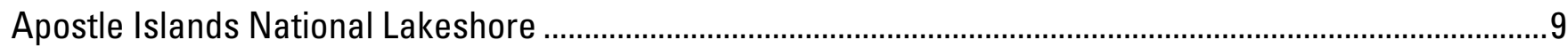

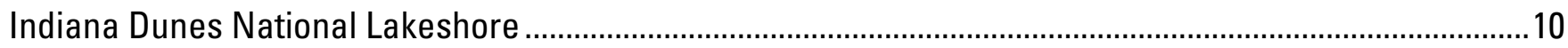

Sleeping Bear Dunes National Lakeshore ............................................................................................ 10

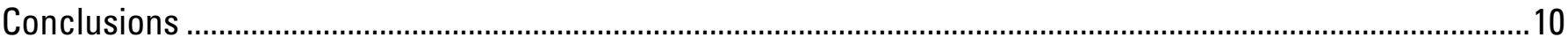

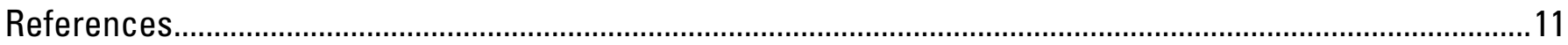

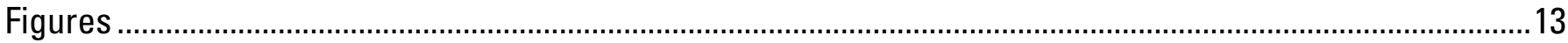

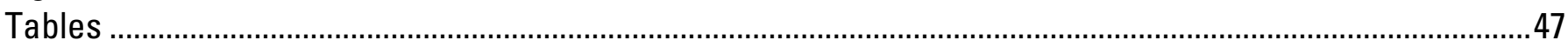




\title{
Coastal Change-Potential Assessment of Sleeping Bear Dunes, Indiana Dunes, and Apostle Islands National Lakeshores to Lake-Level Changes
}

\author{
By Elizabeth A. Pendleton, E. Robert Thieler, and
}

S. Jeffress Williams ${ }^{1}$

\begin{abstract}
A change-potential index (CPI) was used to map the susceptibility of the shoreline to future lake-level change within Apostle Islands, Indiana Dunes, and Sleeping Bear Dunes National Lakeshores (NL) along Lake Superior and Lake Michigan. The CPI in the Great Lakes setting ranks the following in terms of their physical contribution to lake-level related coastal change: geomorphology, regional coastal slope, rate and direction (i.e., rise and fall) of relative lake-level change, historical shoreline change rates, annual ice cover and mean significant wave height. The rankings for each input variable were combined, and an index value calculated for 1-minute bins covering the parks. The CPI highlights those regions where the physical effects of lake-level and coastal change might be the greatest. This approach combines the coastal system's potential for change with its natural ability to adapt to changing environmental conditions, yielding a quantitative, although relative, measure of the park's natural susceptibility to the effects of lakelevel variation. The CPI provides an objective technique for evaluation and long-term planning by scientists and park managers. The CPI is applied to the National Lakeshores of Apostle Islands, Indiana Dunes, and Sleeping Bear Dunes to test this methodology in lake settings. The National Lakeshores in this study consist of sand and gravel beaches, rock outcrops, and dune and glacial bluffs. The areas within these Great Lakes parks that are likely to experience the most lake-levelrelated coastal change are areas of unconsolidated sediment where regional coastal slope is low and wave energy is high.
\end{abstract}

\section{Introduction}

The National Park Service (NPS) is responsible for managing nearly $12,000 \mathrm{~km}(7,500$ miles) of shoreline along oceans and lakes. In 2001, the U.S. Geological Survey (USGS), in partnership with the NPS Geologic Resources Division, began conducting hazard assessments of future sea-level and lake-level change by creating maps to assist NPS in managing its valuable coastal resources. This report presents the results of a potential for change assessment for three National Lakeshores on Lake Superior and Lake Michigan, highlighting areas that are likely to be most affected by climate change-induced lake-level changes.

Based on results of global climate models, the Great Lakes region is expected to experience warmer and drier climate conditions into the next century, which will likely result in a drop in lake levels (only one model, HadCM2, suggests that lake levels may rise) (U.S. Global Change Research Program, 2000). The magnitude and the timing of climate changes are uncertain, but 
recent studies show that the current drop in lake levels (since 1998) are the largest since the Dust Bowl of the 1930's, and are likely a result of higher than average air temperatures over the Great Lakes (Assel and others, 2004). Impacts associated with expected lake-level falls over the next century include decreases in winter ice volume on all the lakes and subsequent warmer water. Winter ice cover also helps to protect the shoreline from storm erosion; therefore, a decrease in annual ice cover could lead to greater shoreline erosion (Forbes and others, 2004). Reduced ice cover has already been linked to warmer than average air temperature associated with El Niño years in the Great Lakes (Nicholls, 1998). Warmer air temperatures could lead to increased evaporation that combined with warmer water would likely increase storminess. An increase in the frequency of storm conditions on the Great Lakes would produce more energy capable of eroding shorelines. Decreases in lake levels could reduce groundwater recharge, causing streams and wetlands to shrink or disappear and threatening groundwater resources in coastal zones. Shipping costs are likely to increase with lake-level decreases as harbor and channel dredging needs increase, and contaminated sediments could become exposed (U.S. Global Change Research Program, 2000).

Throughout the 1900s, the Great Lakes showed a general trend of increasing lake levels with years in the 1970s and 1980s producing record lake-level highs (Figure 1). More recently, however, lake levels appear to be falling near to the long-term average. Because the exact response of lake levels to climate change is uncertain, there is a need in the geologic discipline to address the potential response of the lakeshore to water-level change. The Great Lakes have been proposed as a more manageable test environment than oceans for predicting shoreline response to water-level change (Hands, 1984). However, an accurate and quantitative approach to predicting shoreline change to water-level fluctuation in lakes or oceans is difficult to establish. Even the kinds of data necessary to predict response are the subject of scientific debate. A number of predictive approaches have been proposed (National Research Council, 1990 and 1995), including: 1) extrapolation of historical data (e.g., coastal erosion rates), 2) static inundation and withdrawal modeling, 3) application of a simple geometric model (e.g., the Bruun Rule), 4) application of a sediment dynamics/budget model, or 5) Monte Carlo (probabilistic) simulation based on parameterized physical forcing variables. However, each of these approaches has inadequacies or can be invalid for certain applications (National Research Council, 1990). Additionally, shoreline response to lake-level change is further complicated by human modification of the natural coast, such as beach nourishment projects, and engineered structures such as seawalls, revetments, groins, and jetties. Understanding how a natural or modified coast will respond to water-level change is essential for planning and protecting vulnerable coastal resources.

The primary challenge in predicting shoreline response to lake-level change is quantifying the important variables that contribute to coastal evolution in a given area. In order to address the multi-faceted task of predicting lake-level change impact, the USGS has developed and implemented a methodology to identify areas that may be most likely to experience coastal change (Thieler and Hammar-Klose, 1999). This technique, known as the Coastal Vulnerability Index (CVI), utilizes different ranges of vulnerability (low to very high) to describe a coast's susceptibility to physical change as sea level rises. The coastal vulnerability index was modified for coasts where water level is falling; a slightly different index was developed, the coastal changepotential index (CPI). The CPI used here is similar to the CVI and focuses on six variables that strongly influence coastal evolution on the Great Lakes:

1. Geomorphology

2. Historical shoreline change rate

3. Regional coastal slope 
4. Relative sea-level change

5. Mean significant wave height

6. Mean annual ice cover

These variables can be divided into two groups: 1) geologic variables and 2) physical process variables. The geologic variables are geomorphology, historic shoreline change rate, and regional slope; they contribute to a shoreline's relative resistance to erosion, long-term erosion/accretion trend, and its relative potential for lateral change in the position of the lake-land boundary respectively. The physical process variables include significant wave height, annual ice cover, and lake-level change, which contribute to erosion hazards over time scales from hours to centuries. A relatively simple change potential ranking system (Table 1) allows the six variables to be incorporated into an equation that produces a change-potential index (CPI). The CPI can be used by scientists and park managers to evaluate the likelihood that physical change may occur along a shoreline as lake levels continue to change. Additionally, NPS staff may incorporate information provided by this change-potential assessment technique into general management plans.

\section{Background of CPI}

The change-potential index (CPI) for assessing susceptibility to coastal change associated with water-level change was derived from a similar methodology called the Coastal Vulnerability Index (CVI), which was designed to highlight the vulnerability of a coast to sea-level rise impacts (Thieler and Hammar-Klose, 1999). Potential impacts associated with sea-level rise include shoreline erosion, saltwater intrusion into groundwater aquifers, inundation of wetlands and estuaries, and threats to cultural and historic resources as well as infrastructure. Impacts from lakelevel fall in places along the Great Lakes could include dewatering of wetland areas, decreases in harborage area, channel shoaling, stream and river mouth erosion, habitat loss, and possible reactivation of stable dune systems. A goal of the USGS/NPS cooperative project was to apply CVI methodology in a variety of sea and lake-level settings, so three Great Lakes parks were selected as locations where lake-levels are falling. Because the impacts associated with water-level rise are different from impacts associated with water-level fall, a slightly different index was developed to differentiate assessments in water-level falling areas from water-level rising areas. In this study, we considered that impacts are often evaluated from a human perspective and a human connection to the coast. Threats to infrastructure, for example, are a major concern along shorelines that are experiencing water-level rise. Alternatively, the potential subaerial exposure of polluted lake sediments may be a primary concern in areas where water-level is falling. For the purposes of this cooperative project we chose to reserve the word 'vulnerability' for shorelines that may experience loss of land, infrastructure, or natural and cultural resources as a result of sea level rise. Alternatively, for areas where water-levels are falling and associated impacts are not as wellunderstood or researched, we address the likelihood that coastal change may occur without assigning a subjective term such as risk, hazard, or vulnerability.

In order to apply the CPI method to an emerging lakeshore, an assumption is made that independent of the net movement of water level relative to the land surface, the variables that are most important to coastal change and shoreline evolution will be the same. That is, the six variables defined in the CPI methodology will be important for both submerging (experiencing relative water-level rise) and emerging (experiencing relative water-level fall) coastlines. Since the CPI is designed to highlight change potential based on variables that are common to almost all coasts without directly indicating a physical effect, it should be amenable to application in a variety of geologic settings. The complications with CPI or CVI methods arise after change potential or 
vulnerability has been determined and the possible impacts associated with water-level change are considered. Although this methodology can be applied anywhere that physical change is likely to occur as a result of changing water level, the kinds of change that may occur (i.e. exposure of polluted marine sediments, loss of wetland, erosion of river mouths, lower-groundwater levels)) are not addressed and should be considered by planners in the context of resources utilization and preservation. This report illustrates that CPI methodology can be applied along three lakeshores within the Great Lakes. The application of the data for planning purposes is a function of the nature of potential environmental change and whether such change is desirable from a resource management perspective.

\section{Data Ranking System}

Table 1 shows the six variables described in the Introduction, which include both quantitative and qualitative information. The five quantitative variables are assigned a changepotential ranking based on their actual values, whereas the non-numerical geomorphology variable is ranked qualitatively according to the relative resistance of a given landform to erosion. Shorelines with erosion/accretion rates between zero and $+1.0 \mathrm{~m} / \mathrm{yr}$ are ranked as being of low change potential. Increasingly higher erosion/accretion rates are ranked as correspondingly higher change potential. Regional coastal slopes range from very high change potential, $<0.30$ percent, to very low change-potential at values $>1.20$ percent. The rate of relative lake-level change is ranked such that zero change in lake level is very low change potential and greater than six mm of rise or fall per year is very high change potential. Mean wave height contributions to change potential range from very low $(<.55 \mathrm{~m})$ to very high $(>1.25 \mathrm{~m})$. Mean annual ice cover values were ranked such that regions with no annual ice cover were very high change potential and areas with greater than 130 days of ice cover were very low change potential.

\section{The Great Lakes National Lakeshores}

The Great Lakes enclose the largest single mass of fresh water in the world. The three National Lakeshores presented in this report, Apostle Islands, Indiana Dunes, and Sleeping Bear Dunes, represent over $400 \mathrm{~km}$ (250 miles) of Great Lakes shoreline (Figure 2). The modern shoreline of the Great Lakes is primarily the result of the Wisconsin glaciation and the subsequent deglaciation. The Laurentide ice sheet of the Wisconsin glaciation reached its maximum extent about 23,000 years BP and had disappeared completely by 8,000 years BP. Ice retreat landforms, such as moraines, and ancient lake-phase shorelines associated with crustal rebound, ice sheet margin, and drainage outlet, stipple the Great Lakes landscape; these features have been further modified during the Holocene by lake-level changes and wind and wave processes. The three National Lakeshores in this CPI report are described in more detail in the following paragraphs.

\section{Apostle Island National Lakeshore}

Apostle Island National Lakeshore lies along the southwestern shore of Lake Superior. The Apostle Island archipelago contains twenty-two islands, twenty-one of which lie within the boundary of Apostle Islands National Lakeshore. A 12-mile sand spit along the Bayfield Peninsula also lies within jurisdiction of the National Lakeshore (Figure 3A). The basement rock of the Apostle Islands is Precambrian sandstone, but the surficial geology is a diverse landscape of weathered sandstone cliffs and glacial till that have been reshaped by lake processes to produce abundant sand beaches and spits. Late Holocene shorelines of Lake Superior fluctuations were mapped within the Apostle Islands by Larsen and others (1999) and are visible within the park as 
well older, higher shorelines from glacial lakes (Teller and Thorleifson, 1983). There are six historic lighthouses within Apostle Islands National Lakeshore as well as cultural resources associated with Native Americans, voyageurs, quarrying, loggers, farmers, and fisherman. For more information on Apostle Islands National Lakeshore see:

http://www2.nature.nps.gov/geology/parks/apis/

\section{Indiana Dunes National Lakeshore}

Indiana Dunes National Lakeshore spans 24 km (15 miles) of Lake Michigan shoreline between Michigan City and Gary, IN (Figure 3B). The beautiful beaches along this stretch of lakeshore are a significant recreational resource for the park and a diverse wildlife retreat situated in a large urban setting. Bedrock lies far beneath the surface and large moraines, beach ridges, and sand dunes preserve a record of the glacial history and subsequent lake-level changes of this area. Indiana Dunes NL at the southern end of Lake Michigan represents the largest strandplain of beach ridges in the Great Lakes with about 150 distinct ridges that have evolved over the past 6000 years (Thompson, 1992). In the past 2600 calendar years beach ridges have formed about every 30 years due to lake level changes and the rate of sediment supply to the area (Thompson and Baedke, 1995). Colman and others (2000) estimated that sediments are being deposited in the basin of southern Lake Michigan between 4 and 11 times faster than in the 5,000 years before human settlement, which would suggest a higher rate of erosion of the lakeshore due to lake-level change or changes in land use. Indiana Dunes National Lakeshore is home to one of the most diverse biological communities per unit area of any of the national parks. For more information on Indiana Dunes National Lakeshore see: http://www2.nature.nps.gov/geology/parks/indu/index.cfm

\section{Sleeping Bear Dunes National Lakeshore}

Sleeping Bear Dunes National Lakeshore encompasses 103 km (64 miles) of Lake Michigan shoreline including the Manitou Islands (Figure 3C). After the last ice sheet retreated from the region about 12,000 years ago, lake currents, waves, and winds began reshaping the glacial till that was deposited. Today, sand beaches, spits, and bars line the coast and attest to lake and wind processes. Similar to Indiana Dunes NL, Sleeping Bear Dunes NL has successive beach ridges that formed in glacial terrain embayments, such as the one at Platte Bay (Thompson, 1992). The beach-ridge stratigraphy in Indiana Dunes NL represents a more continuous record than Sleeping Bear Dunes because the rate of sediment supply to southern Lake Michigan is higher. Perched dunes and beach dunes, for which the park is well known, sit on top of high glacial bluffs or lie along the beach, and adjust to the prevailing winds from Lake Michigan. In 1995, a nearly 500-m (1600-feet) block of sediment slipped off the bluff near Sleeping Bear Point and into Lake Michigan. This was the third landslide to occur during the 20th century at Sleeping Bear Point. Jaffe and others (1998) believe that these landslides are triggered by an increase in pore pressure between sand grains in the bluff, brought on by snowmelt being trapped behind a frozen bluff face, weakening the bluff. Geophysical techniques revealed another source of potential bluff weakening related to a paleochannel that could act as a conduit for groundwater, reducing sediment strength and promoting slope failure (Barnhardt and others, 2004). In addition to the vast water and geologic resources within the park, Sleeping Bear Dunes provides a diverse habitat for many species; one example is the 160 different species of nesting birds. For more information on Sleeping Bear Dunes National Lakeshore see: http://www2.nature.nps.gov/geology/parks/slbe/index.cfm 


\section{Methodology}

In order to develop a database for a park-wide assessment of coastal change-potential, data for each of the six variables mentioned above were gathered from state and federal agencies (Table 2 ). The database is based on that used by Thieler and Hammar-Klose (1999) and loosely follows an earlier database developed by Gornitz and White (1992). A comparable assessment of the sensitivity of the Canadian coast to sea-level rise is presented by Shaw and others (1998). The database was constructed using a 1:24,000-scale shoreline for Apostle Islands NL, Indiana Dunes NL, and Sleeping Bear Dunes NL. Data for each of the six variables (geomorphology, shoreline change, coastal slope, relative lake-level change, significant wave height, and annual ice cover) were added to the shoreline attribute table using a 1-minute (approximately $1.5 \mathrm{~km}$ ) grid (Figure 4, and Figure 5A, Figure 5B, and Figure 5C). Next each variable in each grid cell was assigned a change-potential value from 1-5 (1 is very low change potential, 5 is very high change potential) based on the potential magnitude of its contribution to physical changes on the coast as lake level fluctuates (Table 1).

\section{Geologic Variables}

The geomorphology variable expresses the relative erodibility of different landform types (Table 1). These data were derived using digital orthophotos provided by NPS GIS resources and Michigan and Indiana State GIS organizations (Table 2). The Apostle Islands NL, Indiana Dunes NL, and Sleeping Bear Dunes NL contained several geomorphology types, including low to very low change-potential rock bluffs, moderate change-potential alluvial and glacial deposits and beaches backed by cliffs, and high and very high change-potential gravel and sand beaches and spits (Figure 6A, Figure 6B, and Figure 6C).

Shoreline erosion and accretion rates for Indiana Dunes NL and Sleeping Bear Dunes NL National Lakeshores were derived from Great Lakes shoreline recession data (Stewart, 1994) (Table 2). There were no historic shoreline data available for Apostle Islands NL so erosion rates were estimated based on NPS publications (Woolpert, 2003), significant wave heights, and lakeshore lithology (Figure 7A, Figure 7B, and Figure 7C). Shoreline change-potential was not assigned to the very low or very high categories. For Apostle Islands NL and also the Manitou Islands in Sleeping Bear Dunes NL, where historic rates were not available, rock cliff areas were assigned low shoreline change-potential because rock cliffs are not likely to experience significant erosion or accretion annually. Unconsolidated sediments were generally classified as moderate shoreline change-potential. Beaches along the exposed coast were classified as high changepotential. The shoreline change-potential within each 1-minute grid cell was averaged to determine the shoreline change-potential used here. Shoreline change-potential for the 3 parks ranges from low change-potential (areas not experiencing significant shoreline change annually, $>+1 \mathrm{~m} / \mathrm{yr}$ ) to high change-potential (areas where shoreline change is $>+2 \mathrm{~m} / \mathrm{yr}$ ).

Regional coastal slope is an indication of the relative potential for change to inundation and the rapidity of shoreline retreat because low-sloping coastal regions should retreat faster than steeper regions (Pilkey and Davis, 1987). The regional slope of the coastal zone was calculated from a grid of topographic and bathymetric elevations extending $5 \mathrm{~km}$ landward and lakeward of the shoreline. Elevation data were obtained from the National Geophysical Data Center (NGDC) as gridded topographic and bathymetric elevations at 0.1 -meter vertical resolution for 30-arc second grid cells (Table 2). Regional coastal slopes for the Apostle Islands NL, Indiana Dunes NL, and Sleeping Bear Dunes NL fall within the very low to very high change-potential category $(<0.30 \%-$ $>1.20 \%$ ) (Figure 8A, Figure 8B, and Figure 8C). 


\section{Physical Process Variables}

The relative lake-level change variable is derived from the change in annual mean water elevation over time as measured at water level recording stations within the Great Lakes. The rate of lake-level change for Lake Superior from 1918-2003 is about $+0.4 \mathrm{~mm} / \mathrm{year}$ and is ranked as low change-potential (Figure 1B) (GLERL, 2006). The rate of lake-level change for Michigan-Huron for the same time period (1918-2003) is $+4.0 \mathrm{~mm} /$ year, and is ranked as moderate change-potential (Figure 1A) (GLERL, 2006). A reason for the difference in the historical magnitude of lake-level change between Michigan-Huron and Superior is that since 1914 outflow for Lake Superior has been regulated by the International Lake Superior Board of Control. Because lake levels have historically been rising through the 20th century, but are predicted to fall as a result of changing climate in the 21st century, change-potential was established based on lake level change (rise or fall) instead of only lake level rise (Figure 9A, Figure 9B, Figure 9C). Data from climate models suggest that Michigan-Huron levels could be declining at an average rate of $13 \mathrm{~mm} / \mathrm{year}$ by 2090, and Superior could fall at a rate of $8 \mathrm{~mm} /$ year by 2090 (U.S. Global Change Research Program, 2000). Based on historical data and predictive models, Michigan-Huron tends to have greater lakelevel variability than Lake Superior (U.S. Global Change Research Program, 2000). Establishing change-potential ranking based on lake-level change captures the variability in historic and future lake-level trends, and identifies the most dynamic systems as likely being the most vulnerable.

Mean significant wave height is used here as a proxy for wave energy which drives coastal sediment transport. Wave energy is directly related to the square of wave height:

$$
\mathrm{E}=1 / 8 \rho \mathrm{gH} 2
$$

where $\mathrm{E}$ is energy density (wave energy per unit area), $\mathrm{H}$ is wave height, $\rho$ is water density and $\mathrm{g}$ is acceleration due to gravity. Thus, the ability to mobilize and transport coastal sediments is a function of wave height squared. In this report, we use hindcast nearshore mean significant wave height data for the Great Lakes for the period 1976-95 obtained from the U.S. Army Corps of Engineers Wave Information Study (WIS) (Hubertz and others, 1996). The model wave heights were compared to historical measured wave height data obtained from the NOAA National Data Buoy Center to ensure that model values were representative of the study area. Mean wave heights for the Apostle Islands NL, Indiana Dunes NL, and Sleeping Bear Dunes NL vary between $0 \mathrm{~m}$ (sheltered areas, very low change potential) to over $1 \mathrm{~m}$ (exposed areas, very high change potential) (Figure 10a, Figure 10B, Figure 10C).

Mean annual ice cover is linked to the protection from storms that an ice-covered coastline receives during the winter months (Forbes and others, 2004). Ice can also cause severe erosion and property damage especially in river settings or around structures not able to withstand ice push (Forbes and others, 2000). For this study, ice cover over decadal time scales is considered a protective agent in reducing storm erosion along the shoreline. Annual ice cover data were obtained from NOAA's Great Lakes Environmental Research Laboratory Annual Ice Cover Atlas (Assel, 2003) (Figure 11). Of the three national lakeshores in this report, the Apostle Islands experience the longest period of annual ice cover, between 60 and 105 days per year (moderate change-potential). Sleeping Bear Dunes and Indiana Dunes experience between 30-45 days per year of annual ice cover (high change potential) (Figure 12A, Figure 12B, Figure 12C). 


\section{Calculating the Change-Potential Index}

The coastal change-potential index (CPI) presented here is similar to the CVI used in Thieler and Hammar-Klose (1999) and Gornitz and others (1994), as well as to the sensitivity index employed by Shaw and others (1998). The CPI allows six variables to be related in a quantifiable manner that expresses the relative change potential of the coast to physical changes due to future lake-level change. This method yields numerical data that cannot be equated directly with particular physical effects. It does, however, highlight areas where the various effects of lake-level change may be the greatest. Once each section of coastline is assigned a change-potential value for each specific data variable, the coastal change-potential index (CPI) is calculated as the square root of the nroduct of the ranked variables divided by the total number of variables;

$$
\mathrm{CPI}=\sqrt{\frac{\left(a^{*} b^{*} c^{*} d^{*} e^{*} f\right)}{6}}
$$

where, $\mathrm{a}=$ geomorphology, $\mathrm{b}=$ shoreline erosion/accretion rate, $\mathrm{c}=$ coastal slope, $\mathrm{d}=$ relative lakelevel change rate, $\mathrm{e}=$ mean significant wave height, and $\mathrm{f}=$ mean annual ice cover. The calculated CPI value is then divided into quartile ranges to highlight different vulnerabilities within the park. The CPI ranges (low - very high) reported here apply specifically to Apostle Islands NL, Indiana Dunes NL, and Sleeping Bear Dunes NL, respectively, and are not comparable to CPI ranges in other parks where the CPI has been employed (i.e. very high change-potential means the same among parks; it's the numeric values that differ). For example, a numeric value that equals very high change potential in one park may equal moderate change potential in another. We believe the approach used in this study best describes and highlights the change-potential specific to individual park units.

\section{Results}

\section{Apostle Islands National Lakeshore}

The CPI values calculated for Apostle Islands NL range from 1.00 to 7.30. The mean CPI value is 3.16; the mode is 1.73 and the median is 3.00 . The standard deviation is 1.36 . The 25 th, 50th, and 75th percentiles are 2.00, 3.00 and 4.30, respectively. Figure 13A shows a map of the coastal change-potential index for Apostle Islands NL. The CPI scores are divided into low, moderate, high, and very high change potential categories based on the quartile ranges and analysis of the data. CPI values below 2.00 are assigned to the low change-potential category. Values from 2.00 to 2.90 are considered moderate change-potential. High change-potential values lie between 3.00 and 4.30. CPI values above 4.30 are classified as very high. Figure 14A shows the percentage of Apostle Islands NL shoreline in each change-potential category. Nearly $300 \mathrm{~km}$ (185 miles) of shoreline is evaluated along the Apostle Islands NL. Of this total, twenty-one percent of the mapped shoreline is classified as very high change potential due to future lake-level change. Thirty percent is classified as high, twenty-five percent as moderate, and twenty-four percent as low change potential.

\section{Indiana Dunes National Lakeshore}

The CPI values calculated for Indiana Dunes NL range from 6.32 to 12.91. The mean CPI value is 10.27; the mode is 10.00 and the median is 10.00 . The standard deviation is 2.11 . The 25 th, 50th, and 75th percentiles are 9.0, 10.0 and 12.0, respectively. Figure 13B shows a map of the 
coastal change-potential index for Indiana Dunes NL. The CPI scores are divided into low, moderate, high, and very high change-potential categories based on the quartile ranges and analysis of the data. CPI values below 9.0 are assigned to the low change-potential category. Values from 9.0 to 10.0 are considered moderate change potential. High change-potential values lie between 10.10 and 12.00. CPI values above 12.00 are classified as very high change potential. Figure 14B shows the percentage of Indiana Dunes NL shoreline in each change-potential category. Nearly 24 $\mathrm{km}$ (15 miles) of shoreline is evaluated along the Indiana Dunes NL. Of this total, twenty-one percent of the mapped shoreline is classified as very high change potential due to future lake-level change. Twenty-three percent is classified as high, twenty-nine percent as moderate, and twenty-six percent as low change potential.

\section{Sleeping Bear Dunes National Lakeshore}

The CPI values calculated for Sleeping Bear Dunes NL range from 3.87 to 8.94. The mean CPI value is 6.07; the mode is 7.07 and the median is 7.07. The standard deviation is 1.32 . The 25th, 50th, and 75th percentiles are 4.50, 7.00 and 7.70, respectively. Figure 13C shows a map of the coastal change-potential index for Sleeping Bear Dunes NL. The CPI scores are divided into low, moderate, high, and very high change-potential categories based on the quartile ranges and analysis of the data. CPI values below 4.5 are assigned to the low change-potential category. Values from 4.50 to 7.0 are considered moderate change potential. High change-potential values lie between 7.00 and 7.70. CPI values above 7.73 are classified as very high change-potential. Figure $14 \mathrm{C}$ shows the percentage of Sleeping Bear Dunes NL shoreline in each change-potential category. Nearly $100 \mathrm{~km}$ (64 miles) of shoreline is evaluated along the Sleeping Bear Dunes NL. Of this total, thirty-seven percent of the mapped shoreline is classified as being at very high changepotential due to future lake-level change. Twenty-three percent is classified as high, eighteen percent as moderate, and nineteen percent as low.

\section{Discussion}

\section{Apostle Islands National Lakeshore}

The data within the coastal change-potential index (CPI) show variability at different spatial scales within Apostle Islands NL. Variables such as lake-level change (low change potential) and annual ice cover (moderate change potential) are constant within the park (Figure 9A and Figure 12A). The variable for shoreline change is primarily low with a few areas of moderate to high values due to higher shoreline-erosion rates (Figure 7A). The significant wave height variable is high to very low, because the archipelago has many shoreline orientations. Different shoreline segments vary from exposed to direct wave energy to completely sheltered from waves (Figure 10A). Geomorphology and regional coastal slope vary from low to very high and very low to very high, respectively. Lakeshore geomorphology within Apostle Islands NL includes exposed bedrock, reworked glacial bluffs, gravel and sand beaches and spits (Figure 6A). Coastal slope is most closely related to the proximity to Bayfield Peninsula and Lake Superior water depth for Apostle Islands NL (Figure 8A). The most influential variables in the CPI assessment for Apostle Islands NL are geomorphology, coastal slope, and significant wave height; therefore they are considered the dominant factors controlling how Apostle Islands NL, will evolve as future lake levels change (Figure 13A). 


\section{Indiana Dunes National Lakeshore}

The data within the coastal change-potential index (CPI) show variability at different spatial scales for Indiana Dunes NL. Variables such as regional coastal slope (very high), lake-level change (moderate), and mean annual ice cover (high) are constant within the park (Figure 8B, Figure 9B, and Figure 12B). The variable for shoreline change is low to high as determined from historic shoreline recession rates (Stewart, 1994) (Figure 7B). The significant wave height variable is high for all of Indiana Dunes NL (Figure 10B). Lakeshore geomorphology within Indiana Dunes is primarily sand beaches backed by dunes (very high) with bluff areas classified from moderate $(<$ $15 \mathrm{~m}$ in height) to low (>15 $\mathrm{m}$ in height) change potential (Figure 6B). The most influential variables in the CPI assessment for Indiana Dunes NL are geomorphology, coastal slope, and shoreline erosion/accretion rate; therefore they are considered the dominant factors controlling how Indiana Dunes NL, will evolve as future lake levels change (Figure 13B).

\section{Sleeping Bear Dunes National Lakeshore}

The data within the coastal change-potential index (CPI) show variability at different spatial scales for Sleeping Bear Dunes NL. Variables, such as lake-level change (moderate) and mean annual ice cover (high), are constant within the park (Figure 9C and Figure 12C). The variable for shoreline erosion/accretion rate is primarily low as determined from historic shoreline recession data (Stewart, 1994) with an area of high change-potential where three major landslides occurred this century (Figure 7C). The significant wave height variable is high to very high for most of Sleeping Bear Dunes NL, but sheltered areas on the Manitou Islands are low change potential (Figure 10C). Lakeshore geomorphology within Sleeping Bear Dunes is primarily sand beaches backed by dunes (very high change potential) with areas of exposed glacial bluff (moderate change potential), and sand and gravel areas (high change potential) (Figure 6C). The most influential variables in the CPI assessment for Sleeping Bear Dunes NL are geomorphology, coastal slope, and significant wave heights; therefore they are considered the dominant factors controlling how Sleeping Bear Dunes NL, will evolve as future lake levels change (Figure 13C).

The most influential variables in the CVI are geomorphology, regional coastal slope, and wave energy; therefore they may be considered the dominant factors controlling how Guam will evolve as sea level rises.

\section{Conclusions}

The coastal change-potential index (CPI) provides insight into the susceptibility of coastal change due to future lake-level change. The maps and data presented here can be viewed in at least two ways:,

1. an indication of where physical changes are most likely to occur as future lake levels rise or fall; and

2. as a planning tool for managing infrastructure, natural, and cultural resources within Apostle Islands NL, Indiana Dunes NL, and Sleeping Bear Dunes NL.

Apostle Islands NL, Indiana Dunes NL, and Sleeping Bear Dunes NL National Park preserve a dynamic natural environment, and they must be understood in order to be managed properly. The CPI is one way that park managers can assess objectively the natural factors that contribute to the evolution of the lakeshore, and thus how the parks may evolve in the future. 


\section{References}

Assel, R.A., 2003, An electronic atlas of Great Lakes ice cover: NOAA Great Lakes Ice Atlas:

Great Lakes Environmental Research Laboratory, Ann Arbor, Mich. 48105.

Assel, R.A., Quinn, F.H., and Sellinger, C.E., 2004, Hydroclimatic factors of the recent record drop in Laurentian Great Lakes water levels: Bulletin of the American Meteorological Society, v. 85, no. 8 , p. 1143-1151.

Barnhardt, W.A., Jaffe, B.E., Kayen, R.E., and Cochrane, G.R., 2004, Influence of near-surface stratigraphy of coastal landslides at Sleeping Bear Dunes National Lakeshore, Lake Michigan, USA: Journal of Coastal Research, v.20. no.2, p. 510-522.

Colman, S.M., King, J.W., Jones, G.A., Reynolds, R.L., Bothner, M.H., 2000, Holocene and recent sediment accumulation rates in Southern Lake Michigan: Quaternary Science Reviews, v. 19 p. 1563-1580.

Forbes, D.L., Parkes, G.S., O'Reilly, C., Daigle, R., Taylor, R., and Catto, N., 2000, Storm-surge, sea-ice, and wave impacts of the 21- 22 January 2000 storm in coastal communities of Atlantic Canada: Program and Abstracts, 34th Congress, Canadian Meteorological and Oceanographic Society, Victoria, BC, p. 82.

Forbes, D.L, Parkes, G.S., Manson, G.K., and Ketch, L.A., 2004, Storms and shoreline retreat in the sourthern Gulf of St. Lawrence: Marine Geology, v. 210, p 169-204.

Gornitz, V. and White, T.W. 1992, A coastal hazards database for the U.S. West Coast: ORNL/CDIAC-81, NDP-043C, Oak Ridge National Laboratory, Oak Ridge, Tenn.

Gornitz, V.M., Daniels, R.C., White, T.W., and Birdwell, K.R., 1994, The development of a coastal vulnerability assessment database; Vulnerability to sea-level rise in the U.S. southeast: Journal of Coastal Research, Special Issue No. 12, p. 327-338.

Great Lakes Environmental Research Laboratory (GLERL), 2006, Great Lakes Water Levels: http://www.glerl.noaa.gov/data/now/wlevels/levels.html, accessed Sept. 2006

Hands, E.B., 1984, The Great Lakes as a test model for profile response to sea level changes: Miscellaneous paper (U.S. Army Engineer Waterways Experiment Station), CERC-84-14, p. 26.

Hubertz, J.M., Thompson, E.F., and Wang, H.V., 1996, Wave information studies of U.S. coastlines; Annotated bibliography on coastal and ocean data assimilation: U.S. Army Engineer Waterways Experiment Station, WIS Report 36, Vicksburg, 31 p.

Jaffe, B., Kayen, R., Gibbon, H., Hendley, J.W., Stauffer, P.H., 1998, Popular beach disappears underwater in huge coastal landslide - Sleeping Bear Dunes, Michigan: U.S. Geolgical Survey Fact Sheet 020-98. 
Larsen, C.E., Cameron, C.C., and Robbins, E.I., 1999, The reconstructed late Holocene lake-level history of the Apostle Islands National Lakeshore, Lake Superior: Program and Abstracts of the 42nd Conference of the International Association for Great Lakes Research, v. 42, p. A66-A67.

National Research Council, 1990, Managing Coastal Erosion, Washington: National Academy Press, 163 p.

National Research Council, 1995, Beach Nourishment and Protection, Washington: National Academy Press, 334 p.

Nicholls, K.H., 1998, El Nino, ice cover, and Great Lakes phosphorus; Implications for climate warming: Limnology and Oceanorgraphy, v. 43, no. 4, p. 715-719.

Pilkey, O.H., and Davis, T.W., 1987, An analysis of coastal recession models, North Carolina coast, in D. Nummedal, O.H. Pilkey, and J.D. Howard, eds., Sea-level Fluctuation and Coastal Evolution: SEPM (Society for Sedimentary Geology) Special Publications No. 41, Tulsa, Okla., p. 59-68.

Shaw, J., Taylor, R.B., Forbes, D.L., Ruz, M.H., and Solomon, S., 1998, Sensitivity of the Canadian coast to sea-level rise: Geological Survey of Canada Bulletin, v. 505, 114 p.

Stewart, C.J., 1994, United States Great Lakes Shoreline Recession Rate Data: A U.S. Army Corps of Engineers and Christian J. Stewart Consulting Report, 78 p. Online.

Teller, J.T., and Thorleifson, L.H., 1983, The Lake Agassiz-Lake Superior connection, in Teller, J.T., Clayton, L., eds., Glacial Lake Agassiz: Geological Association of Canada Special Paper 26, Toronto, p. 261-290.

Thieler, E.R., and Hammar-Klose, E.S., 1999, National Assessment of Coastal Vulnerability to Sea-Level Rise, U.S. Atlantic Coast: U.S. Geological Survey Open-File Report 99-593, 1 sheet. Available online at http://pubs.usgs.gov/of/of99-593/

Thompson, T.A., 1992, Beach-ridge development and lake-level variation in Southern Lake Michigan: Sedimentary Geology, v. 80, p. 305-318.

Thompson, T.A., and Baedke, S.J., 1995, Beach-ridge development in Lake Michigan; shoreline behavior in response to quasi-periodic lake-level events: Marine Geology, v. 129, p. 163-174.

U.S. Global Change Research Program, 2000, U.S. National assessment of the potential consequences of climate variability and chang, Washington, D.C.: U.S. Climate Change Science Program/ U.S. Global Change Research Program.

Woolpert, 2003, Erosion control at Outer Island Light Station, revised environmental assessment: Woolpert LLP, 409 East Monument Ave, Dayton, Ohio, 99 p. (http://www.nps.gov/apis/outerbanks.html). 
Figures

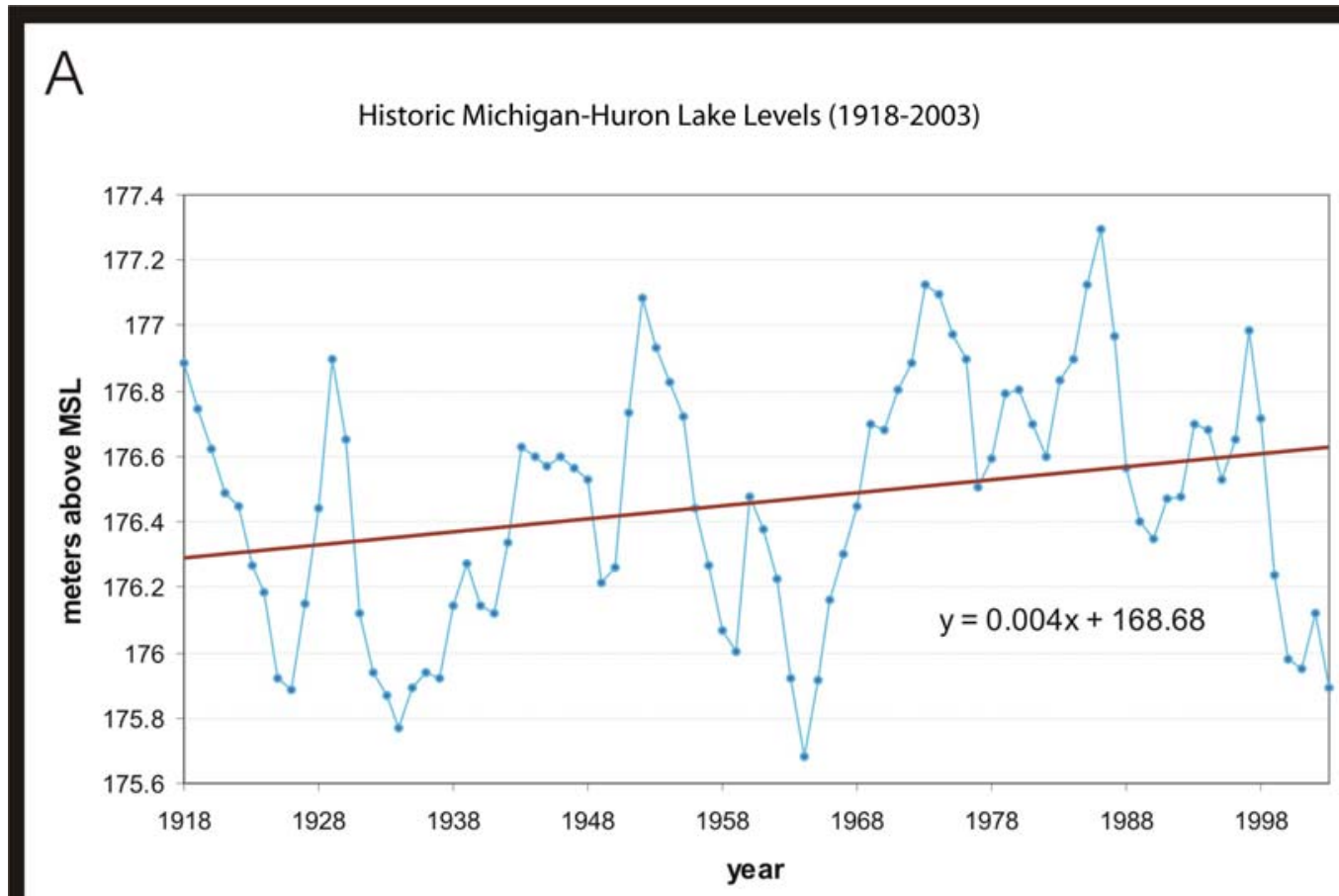

B

Historic Superior Lake Levels (1918-2003)

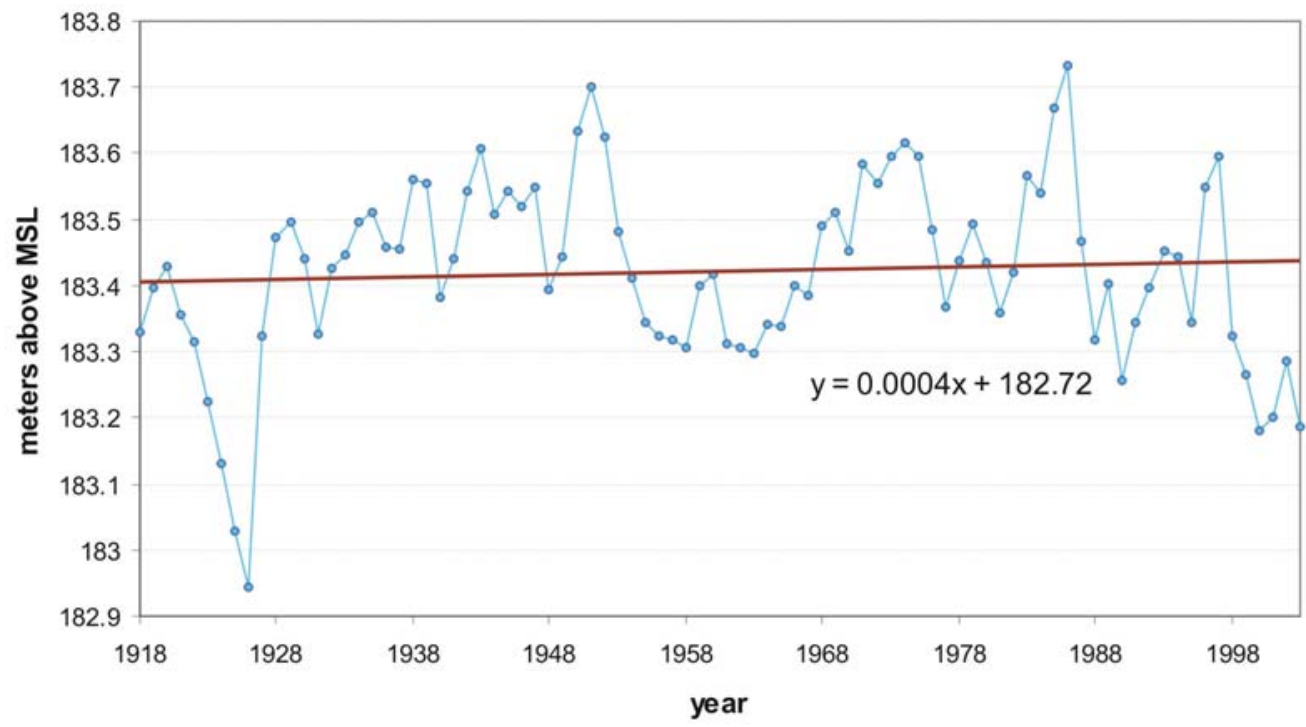

Figure 1. Hydrographs of Lake Michigan-Huron (A) and Lake Superior (B) from 1918 - 2003, lake-level data provided by National Oceanic and Atmospheric Administration Great Lakes Environmental Research Laboratory (http://www.glerl.noaa.gov/). 


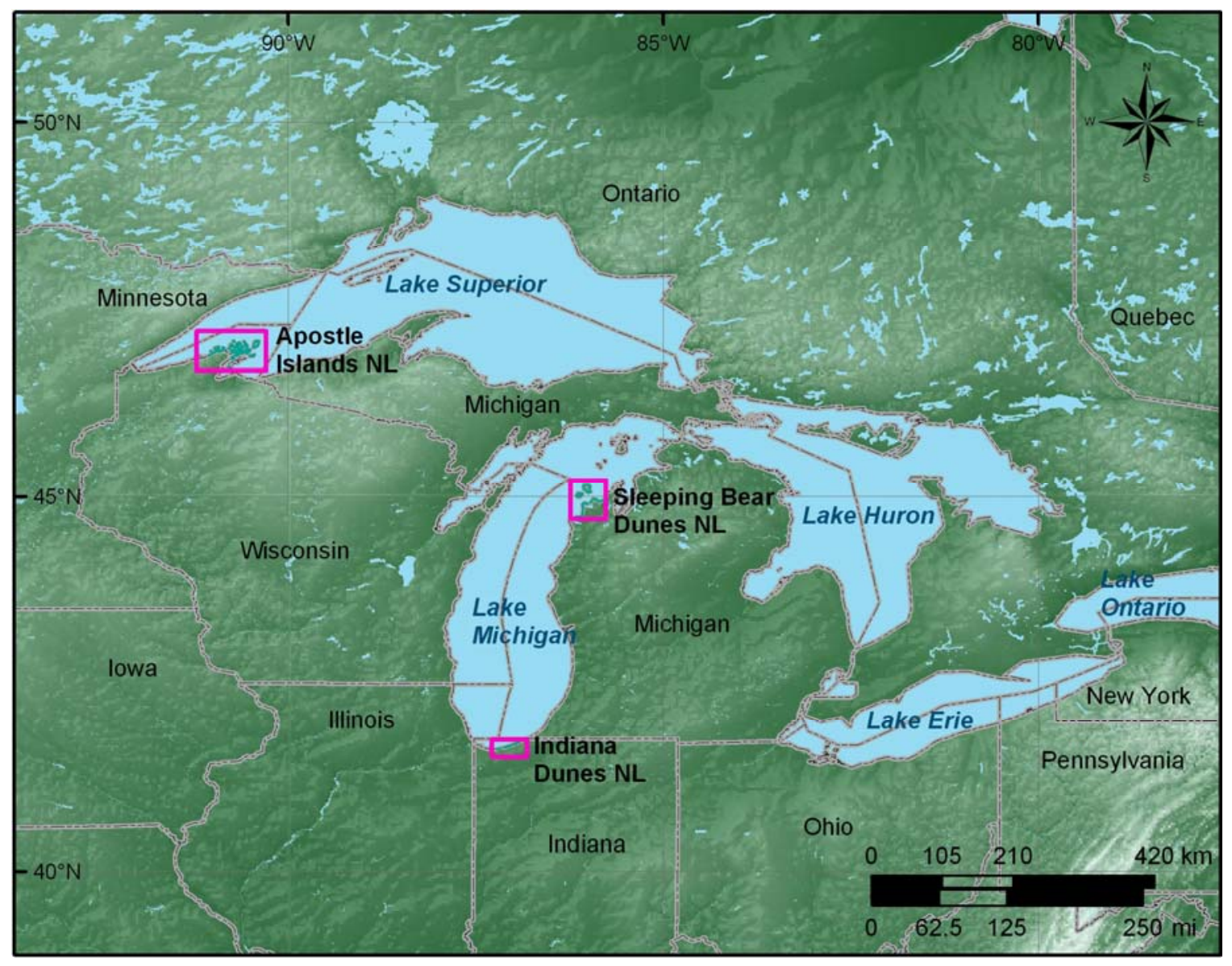

Figure 2. Location of Great Lakes National Lakeshores: Sleeping Bear Dunes, MI; Indiana Dunes, IN; and Apostle Islands, WI. 


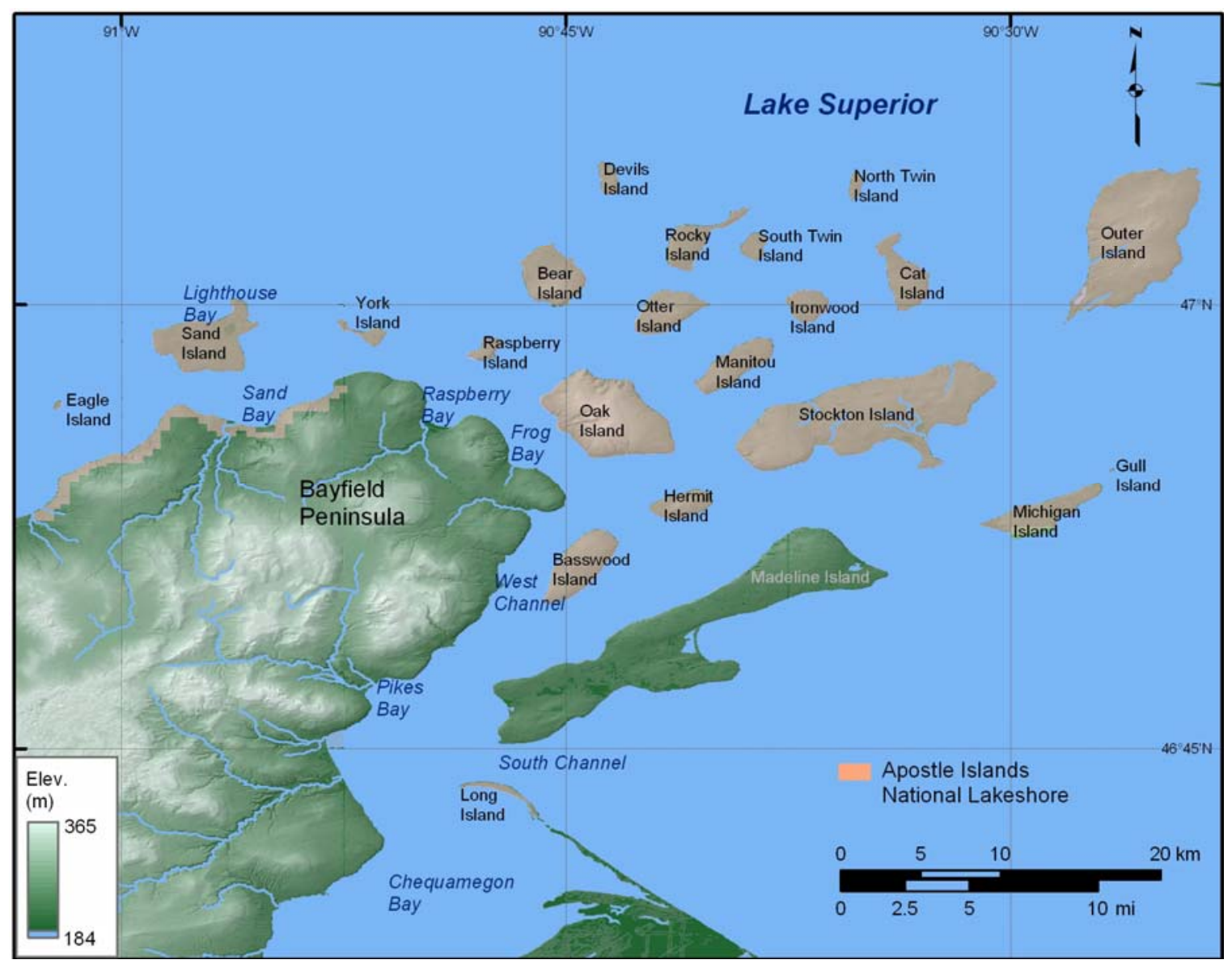

Figure 3A. Detailed map of Apostle Islands National Lakeshore. 


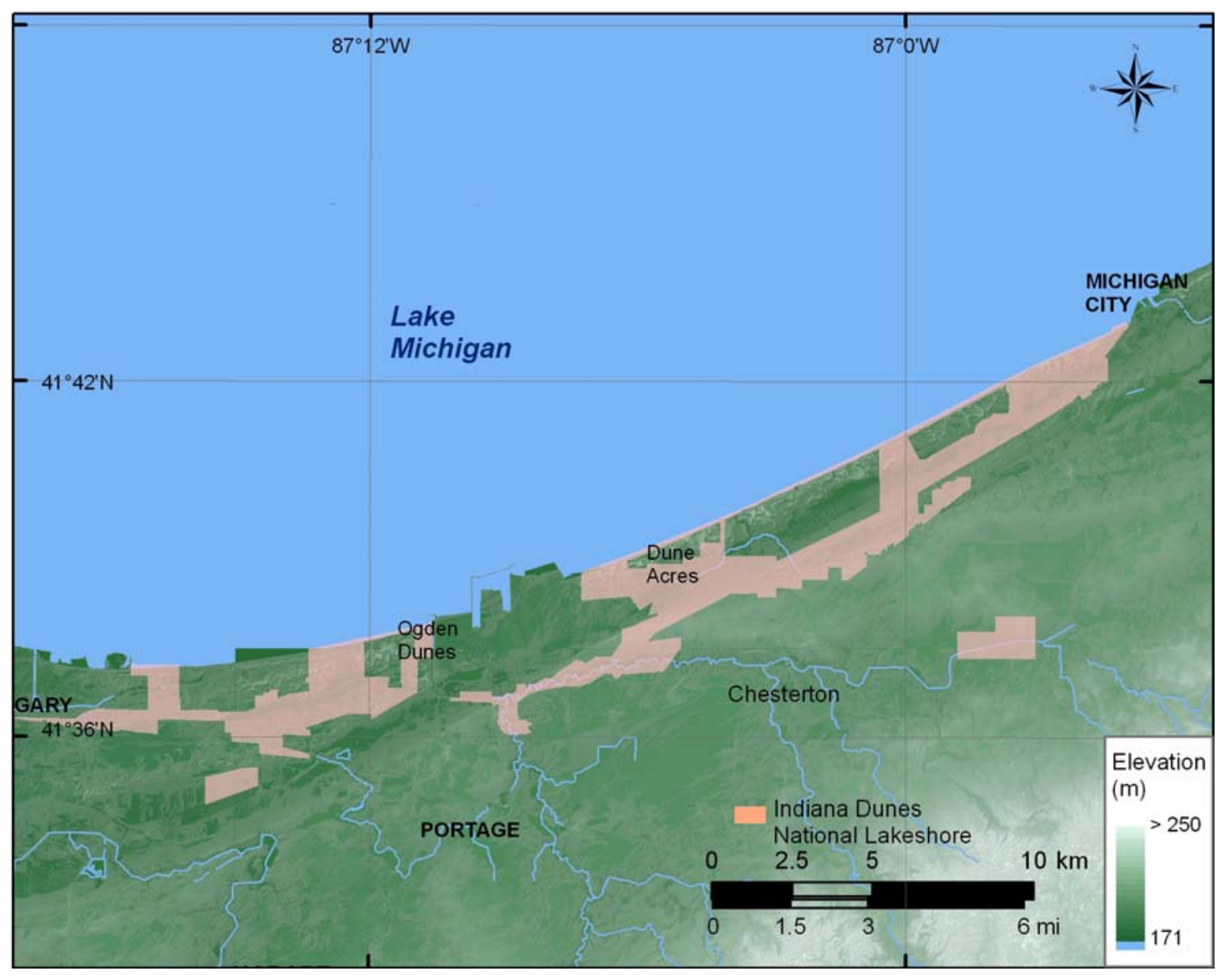

Figure 3B. Detailed map of Indiana Dunes National Lakeshore. 


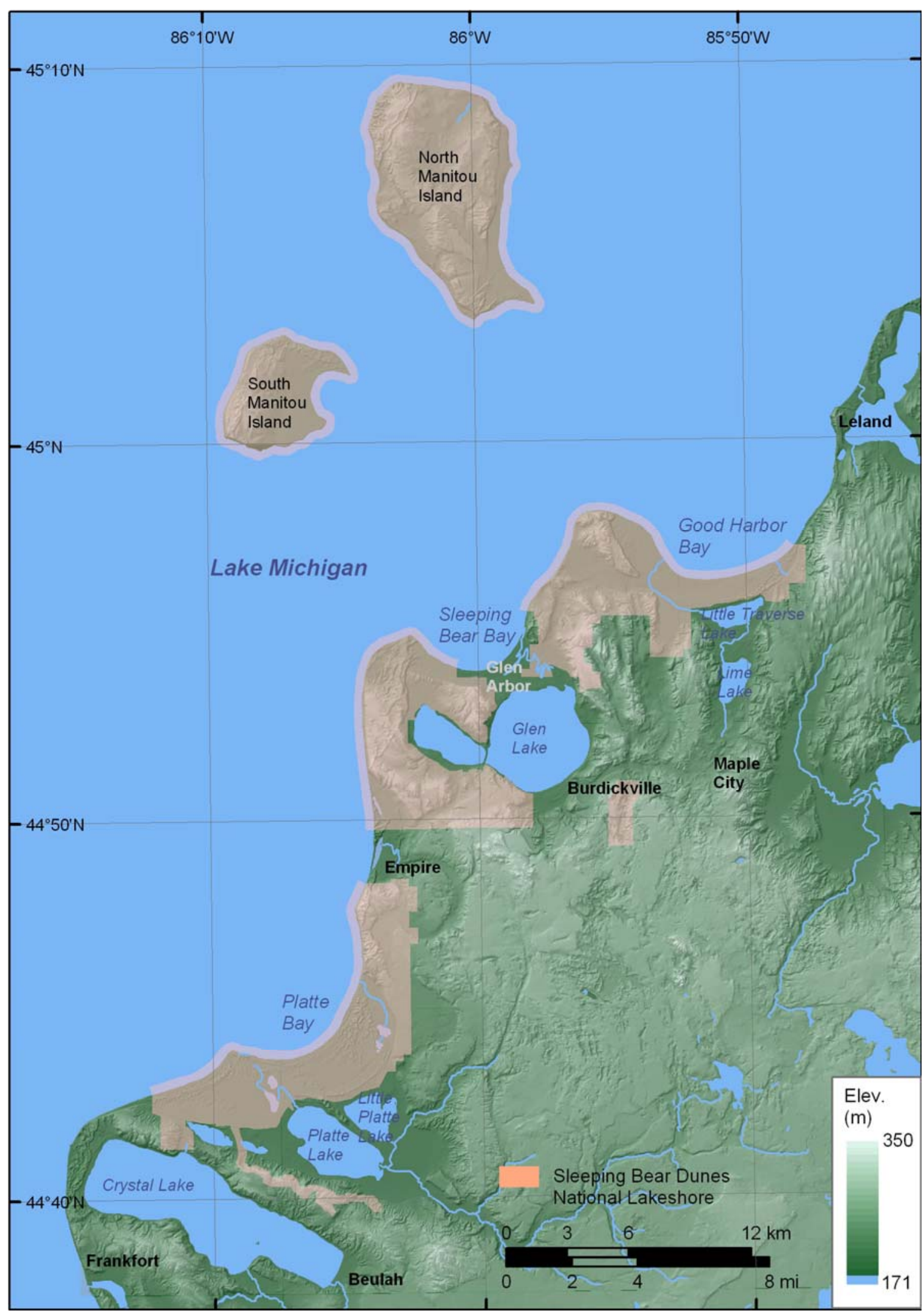

Figure 3C. Detailed map of Sleeping Bear Dunes National Lakeshore. 


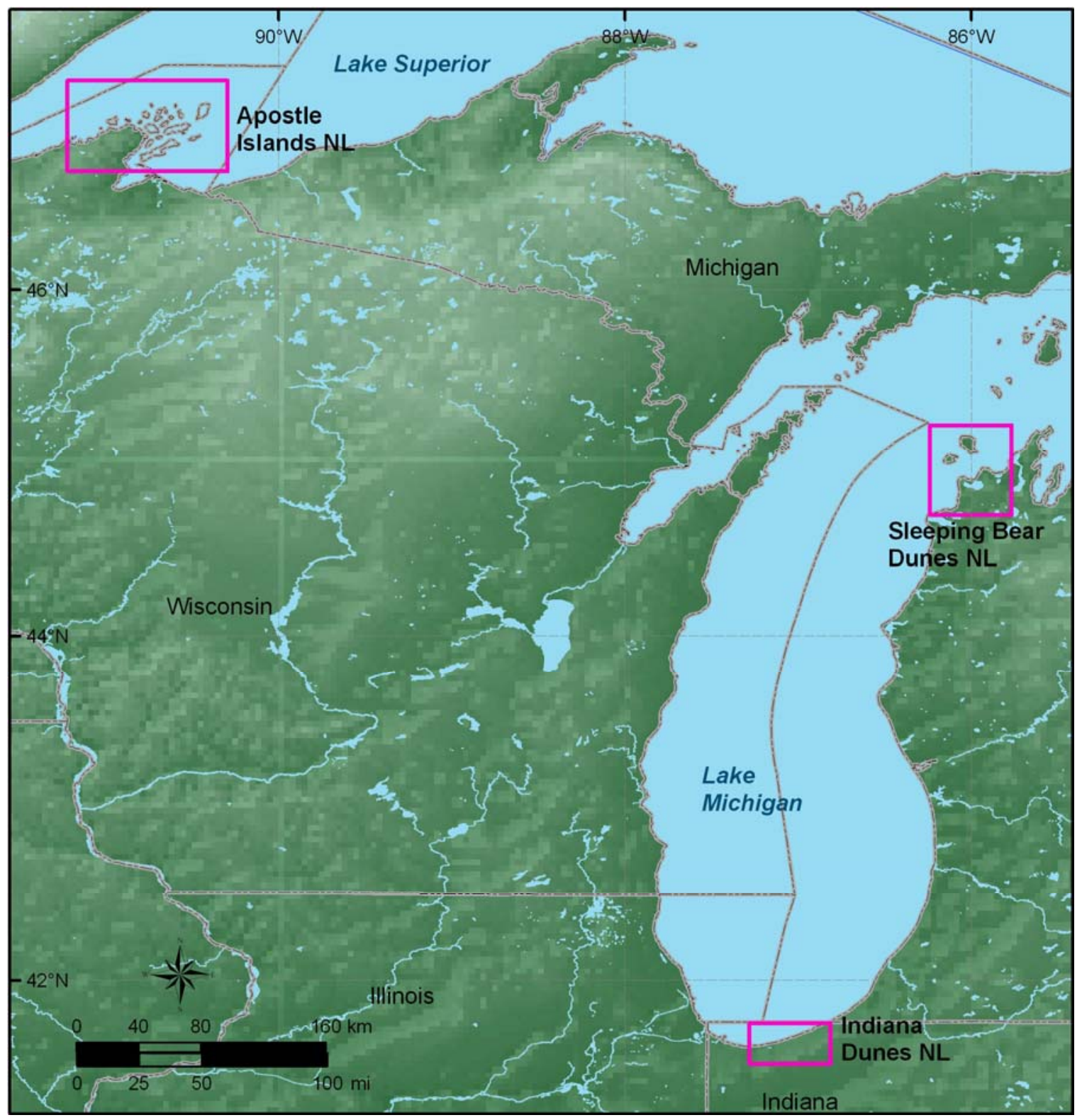

Figure 4. Index map of shoreline grids for Sleeping Bear Dunes NL, Indiana Dunes NL, and Apostle Islands NL. 


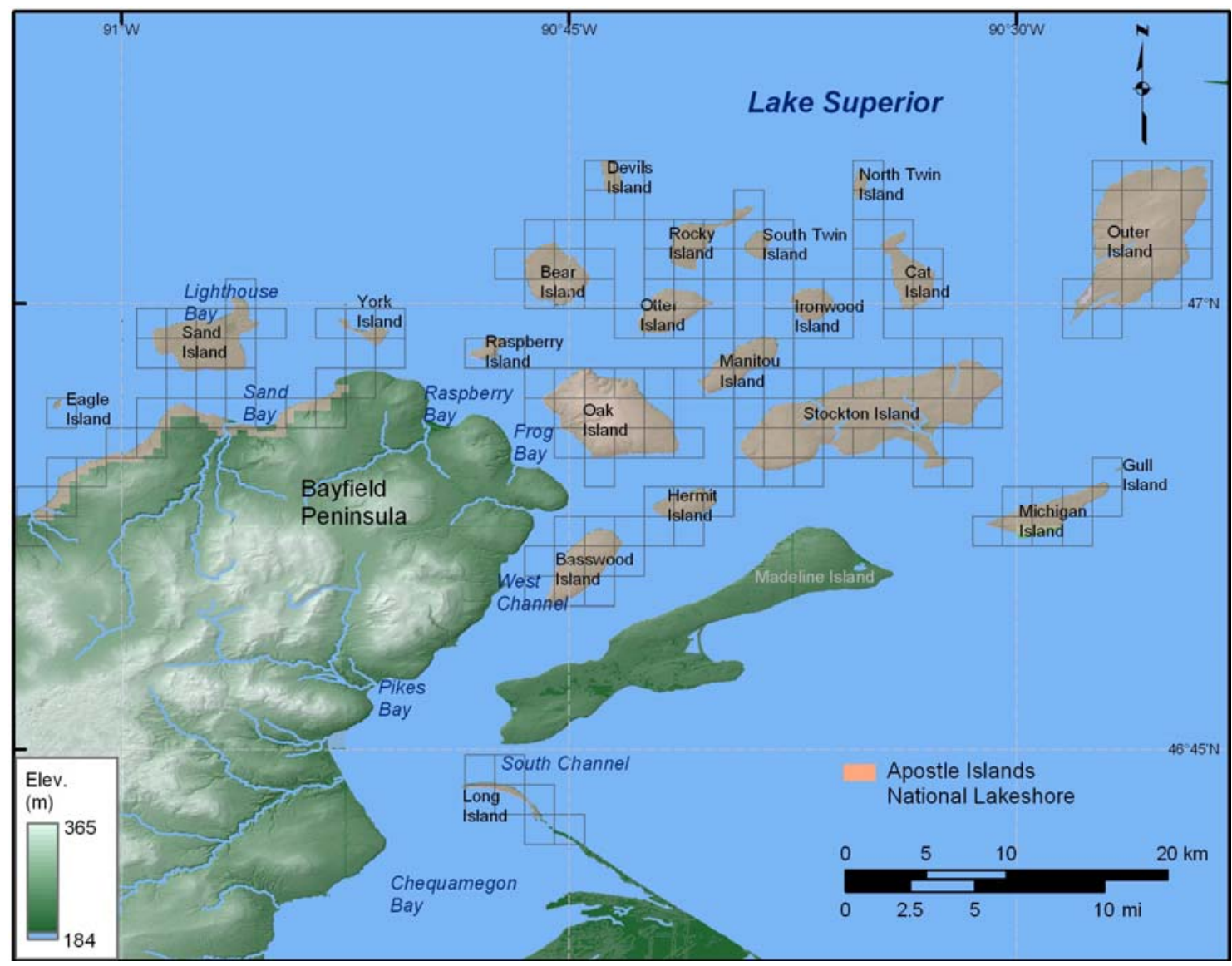

Figure 5A. Shoreline grid for Apostle Islands NL. Each cell is approximately I-minute and represents a shoreline segment for which each variable is defined. 


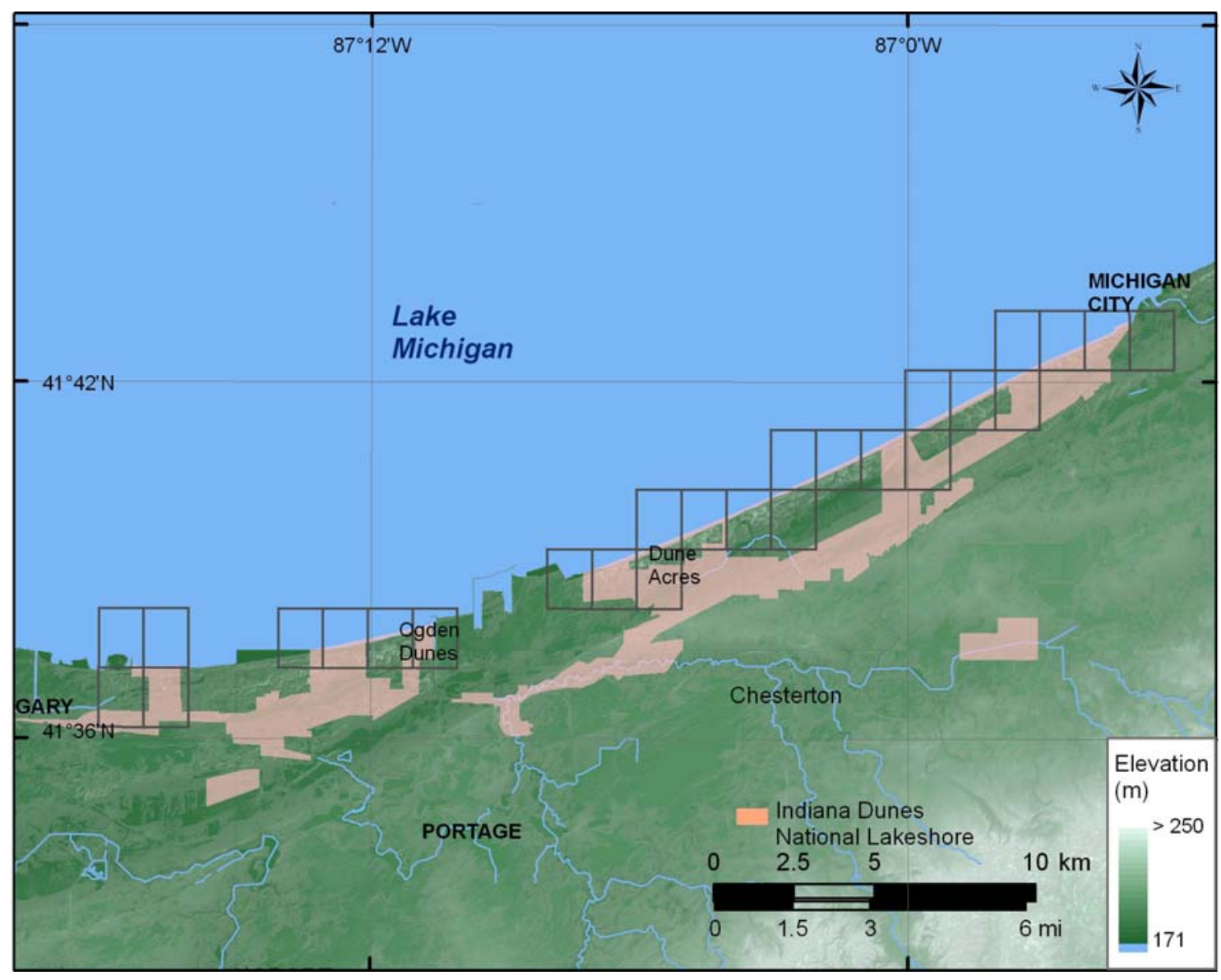

Figure 5B. Shoreline grid for Indiana Dunes NL. Each cell is approximately I-minute and represents a shoreline segment for which each variable is defined. 


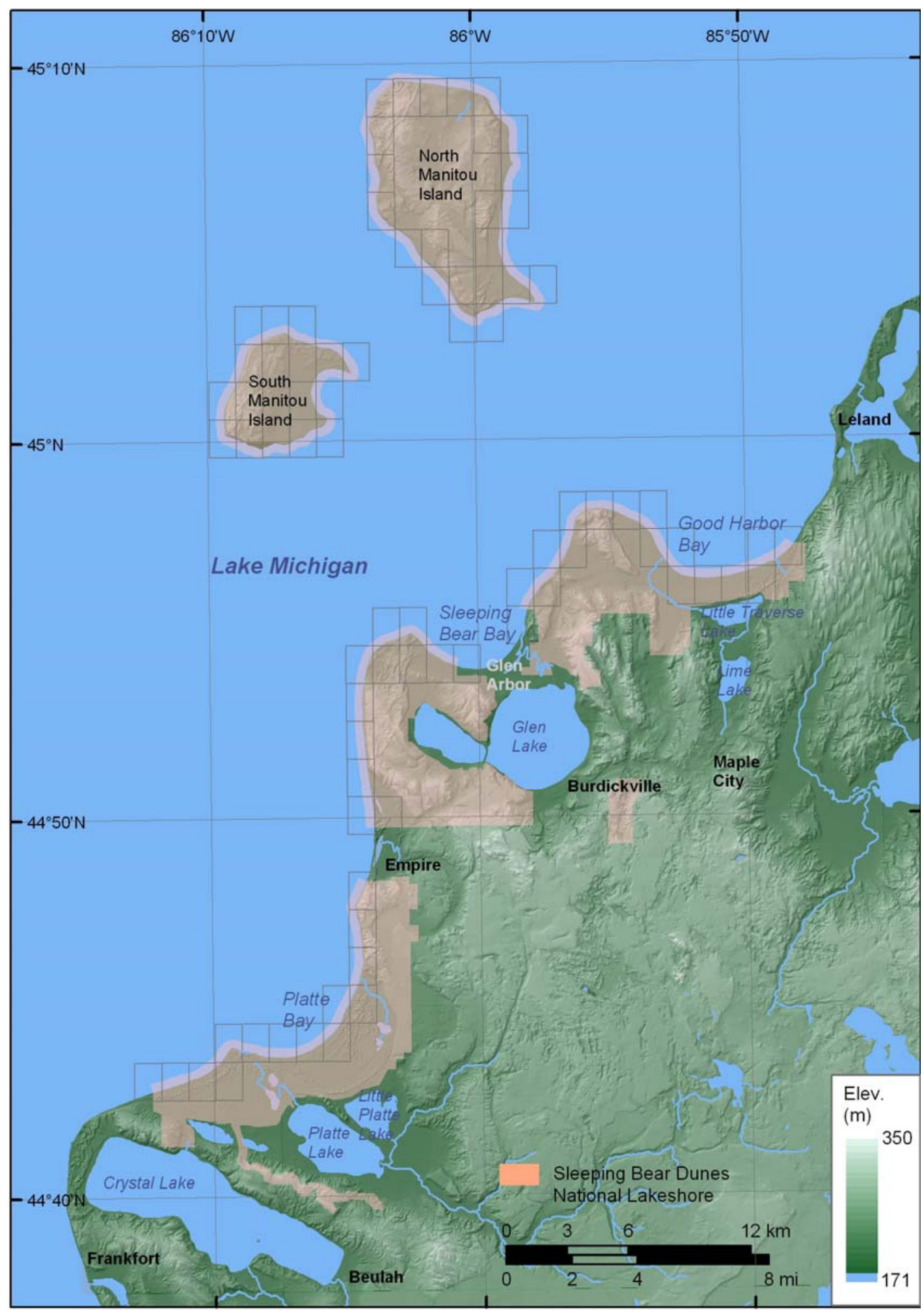

Figure 5C. Shoreline grid for Sleeping Bear Dunes NL. Each cell is approximately Iminute and represents a shoreline segment for which each variable is defined. 


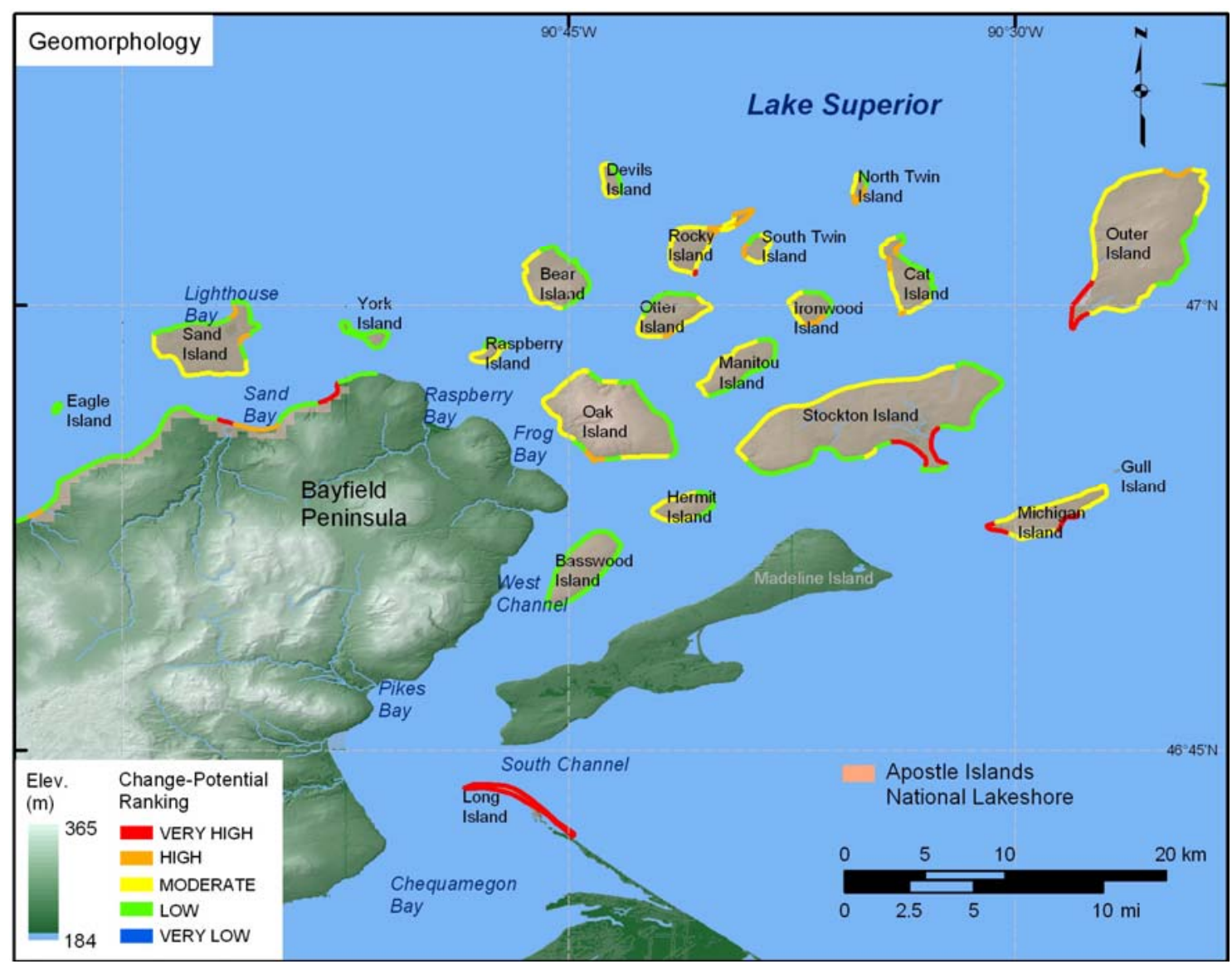

Figure 6A. Lakeshore geomorphology for Apostle Islands National Lakeshore. The colored shoreline represents the variations in coastal geomorphology within the park. High change-potential geomorphology includes gravel and sand beaches not immediately backed by bluffs. Moderate change-potential geomorphology consists of alluvial fans and sand beaches backed by bluffs. Low change-potential geomorphology includes medium bluffs and rock outcrops. 


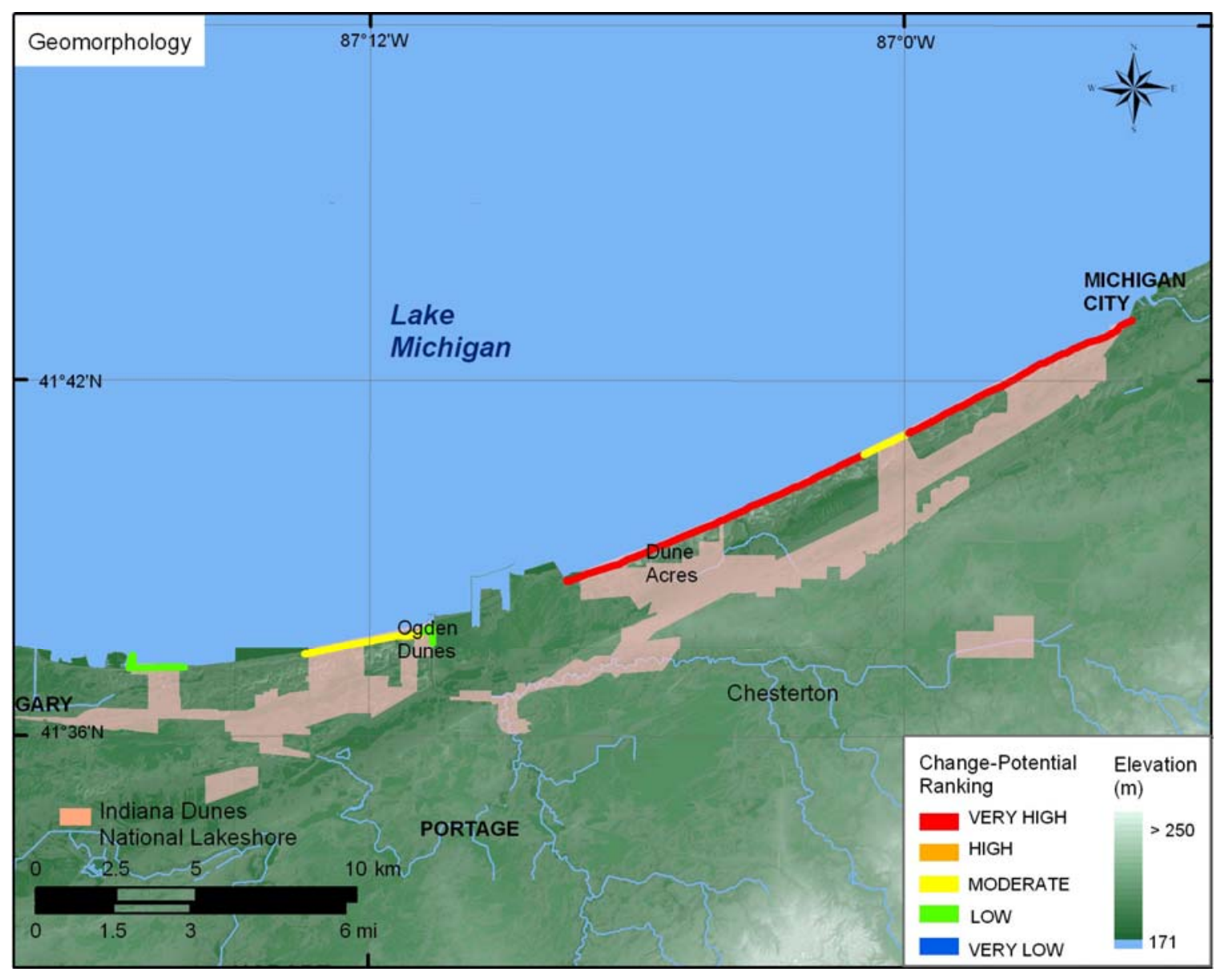

Figure 6B. Lakeshore geomorphology for Indiana Dunes National Lakeshore. The colored shoreline represents the variations in coastal geomorphology within the park. High change-potential geomorphology includes gravel and sand beaches not immediately backed by bluffs. Moderate change-potential geomorphology consists of alluvial fans and sand beaches backed by bluffs. Low change-potential geomorphology includes medium bluffs and rock outcrops. 


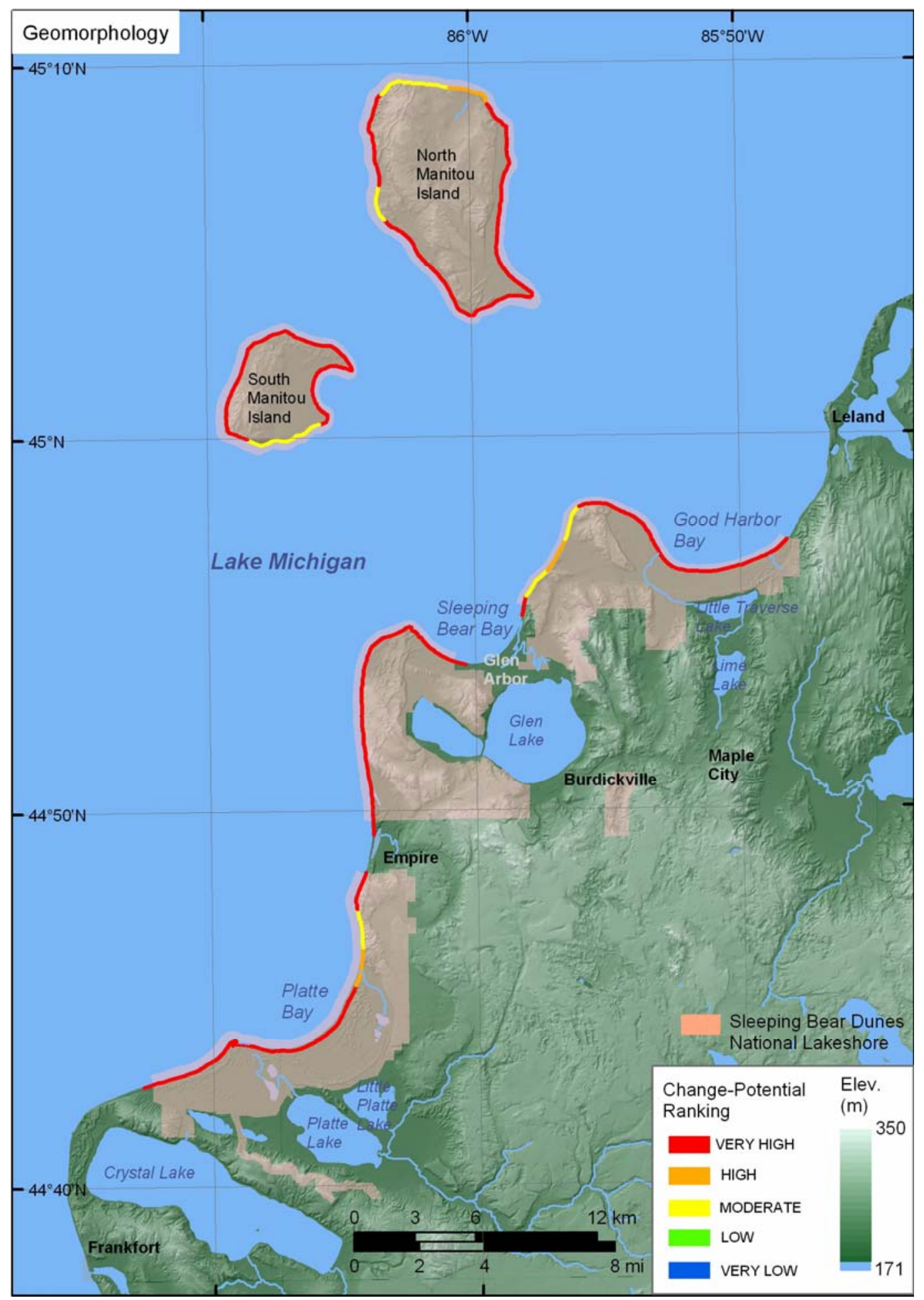

Figure 6C. Lakeshore geomorphology for Apostle Islands National Lakeshore. The colored shoreline represents the variations in coastal geomorphology within the park. High change-potential geomorphology includes gravel and sand beaches not immediately backed by bluffs. Moderate change-potential geomorphology consists of alluvial fans and sand beaches backed by bluffs. 


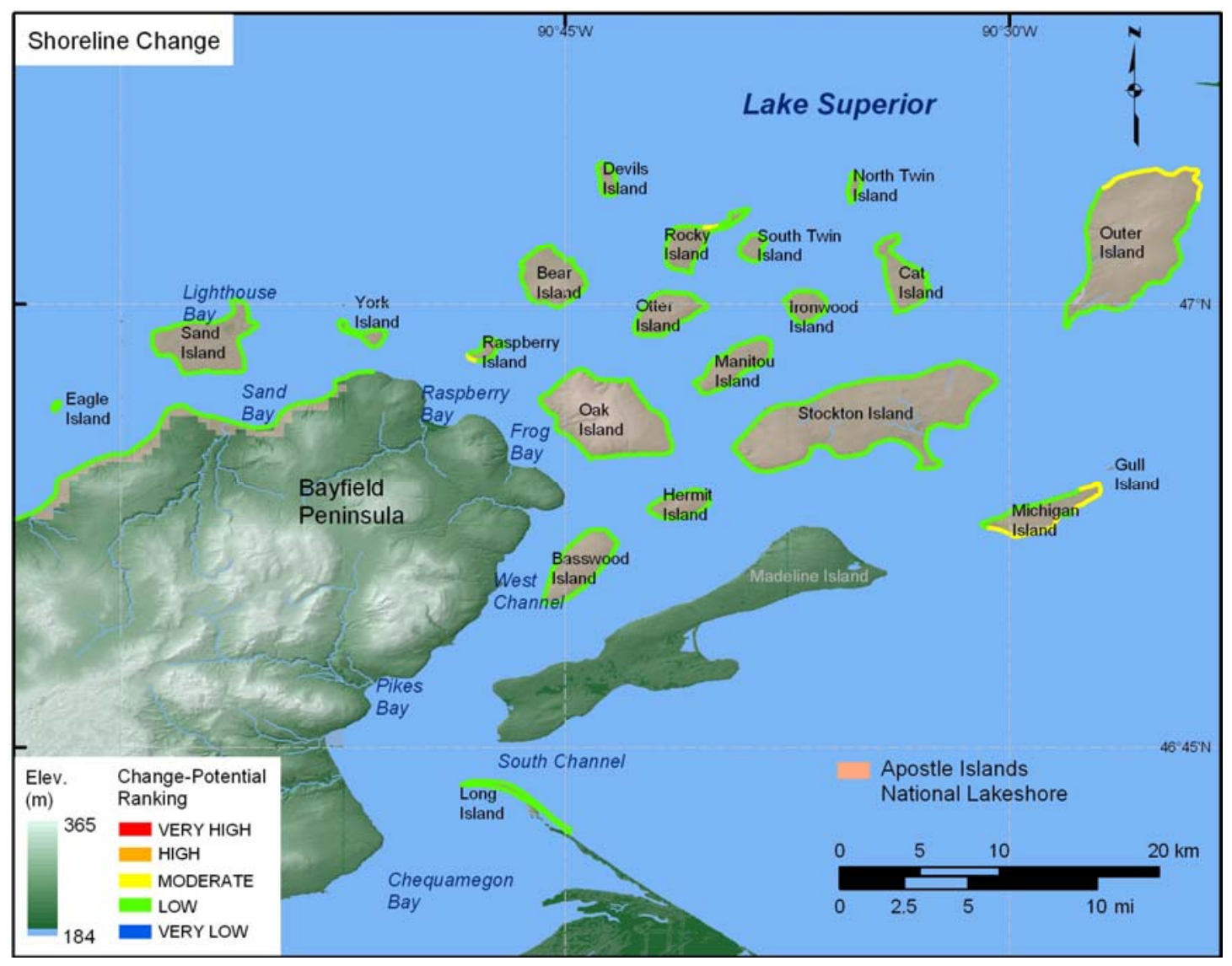

Figure 7A. Shoreline change for Apostle Islands National Lakeshore. The colored shoreline represents the estimated rate of shoreline change. 


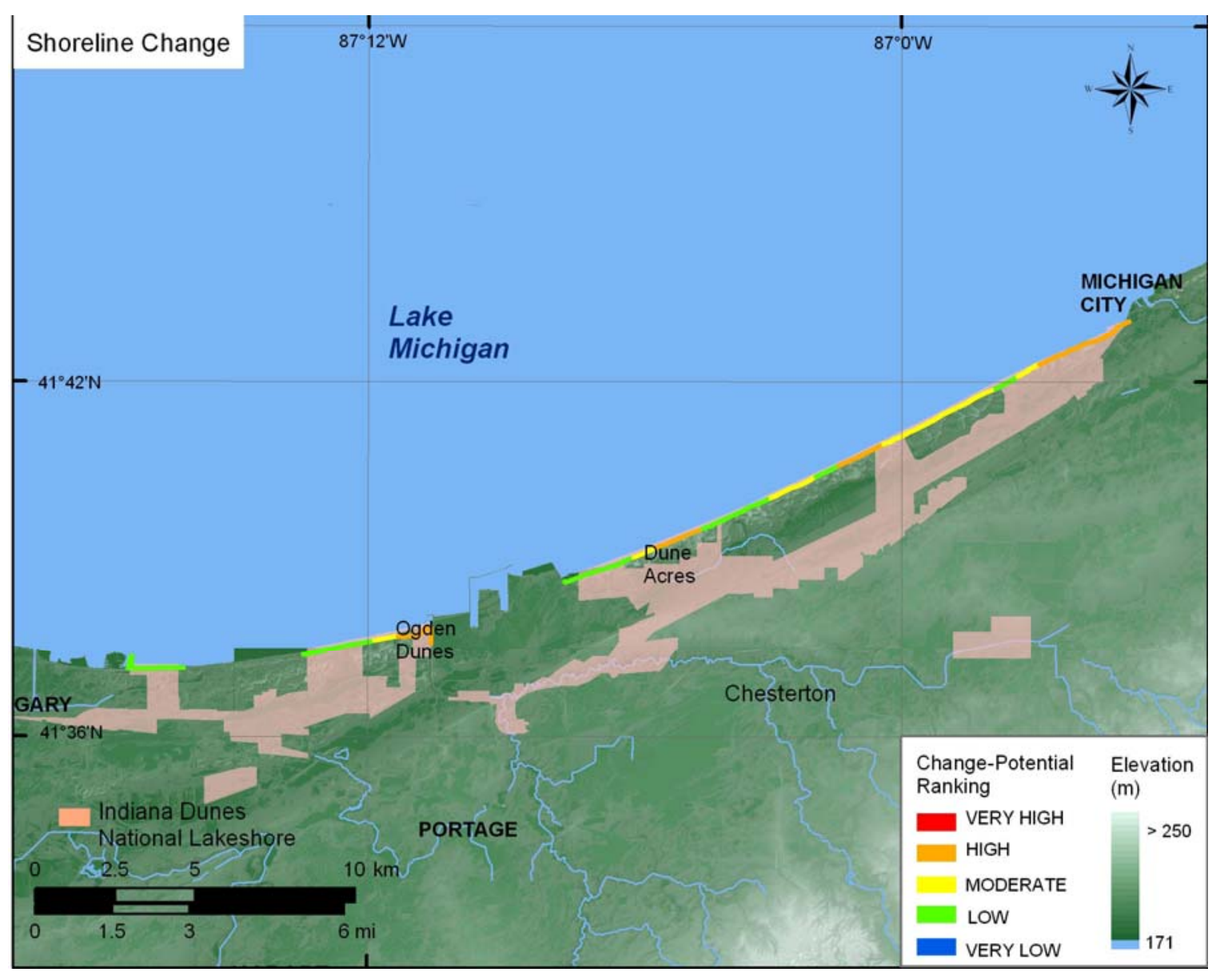

Figure 7B. Shoreline change for Indiana Dunes National Lakeshore. The colored shoreline represents the rate of shoreline change. 


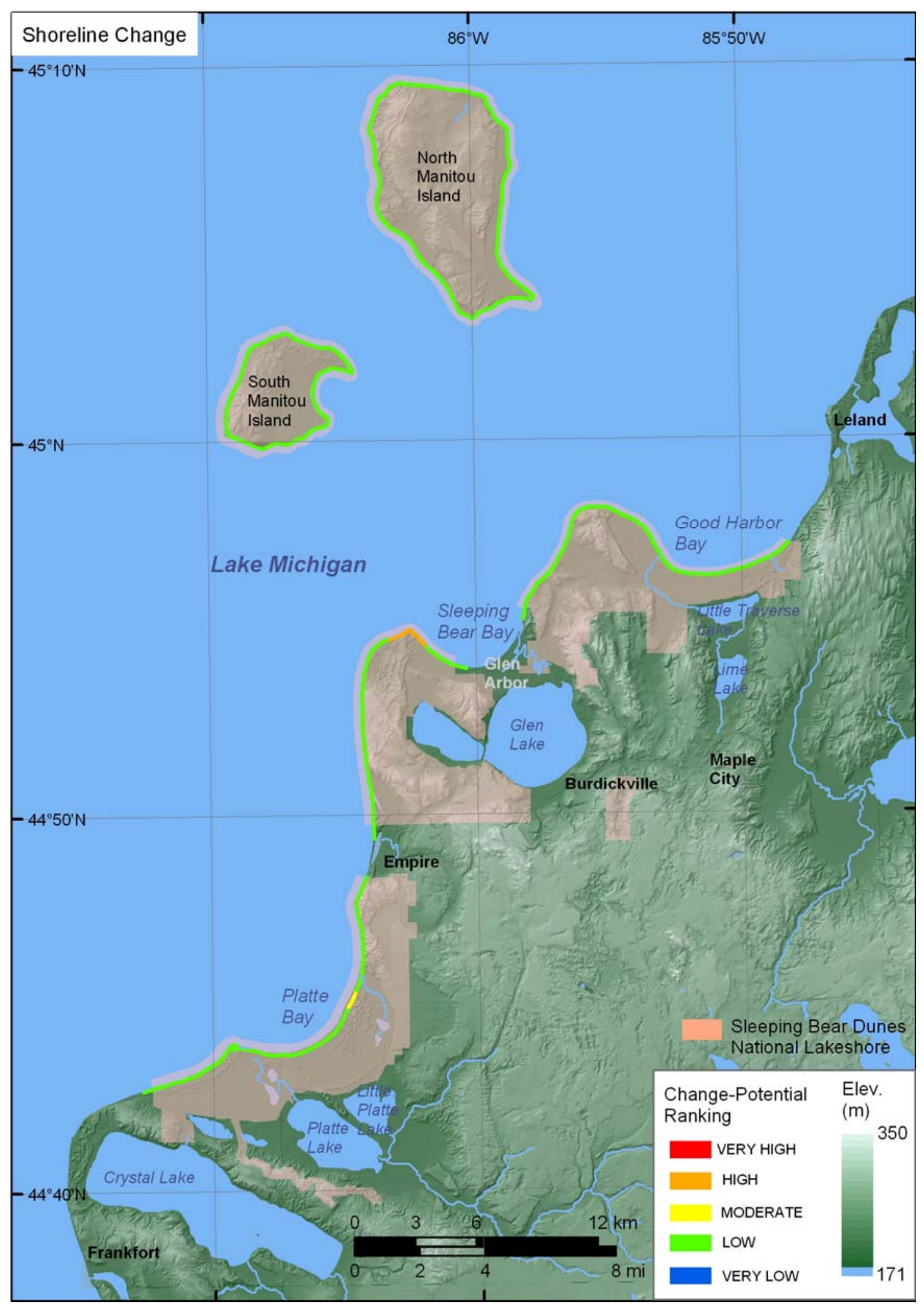

Figure 7C. Shoreline change for Sleeping Bear Dunes National Lakeshore. The colored shoreline represents the rate of shoreline change. 


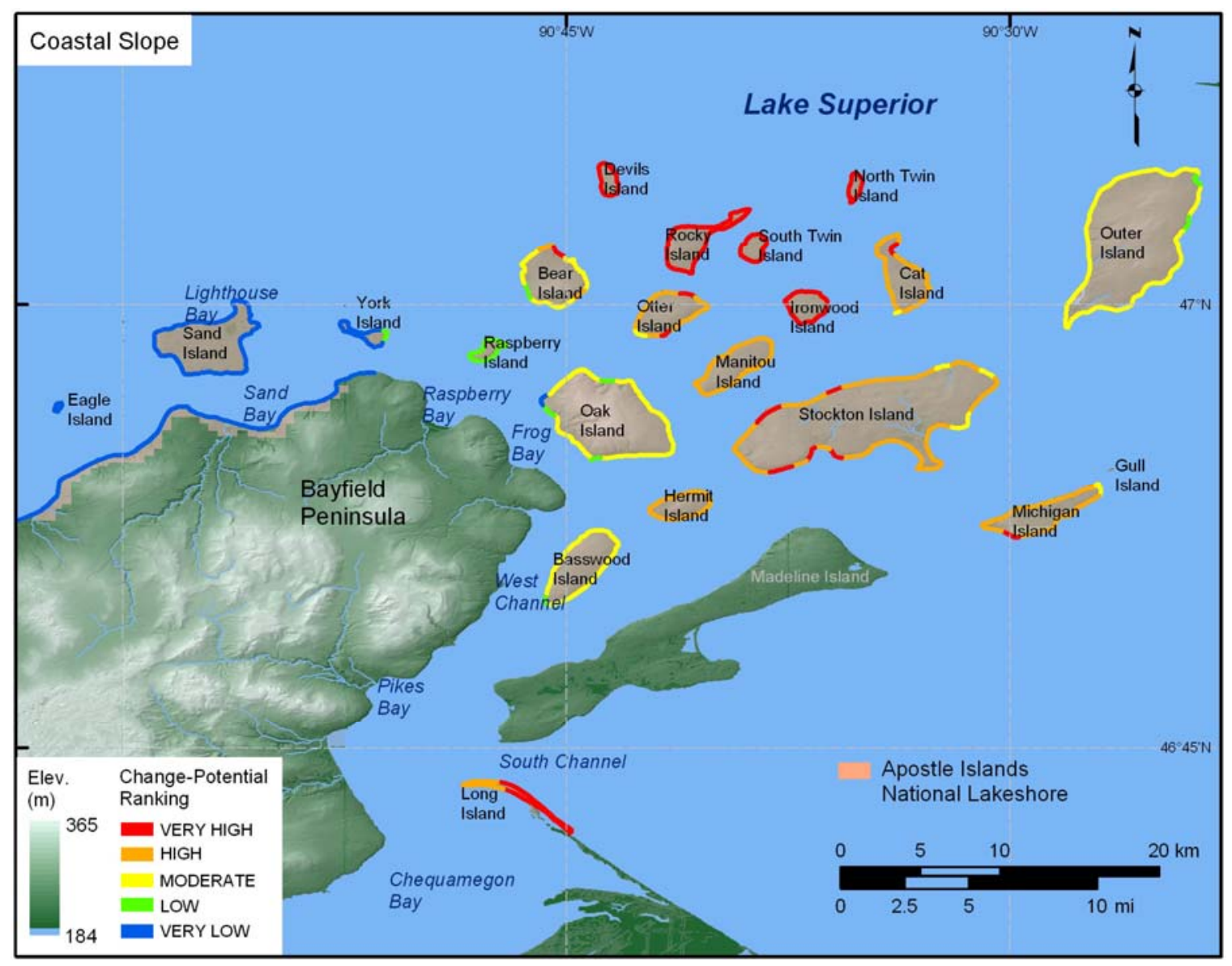

Figure 8A. Regional coastal slope for Apostle Islands National Lakeshore. The colored shoreline represents the regional slope of the land, $5 \mathrm{~km}$ landward and lakeward of the shoreline. 


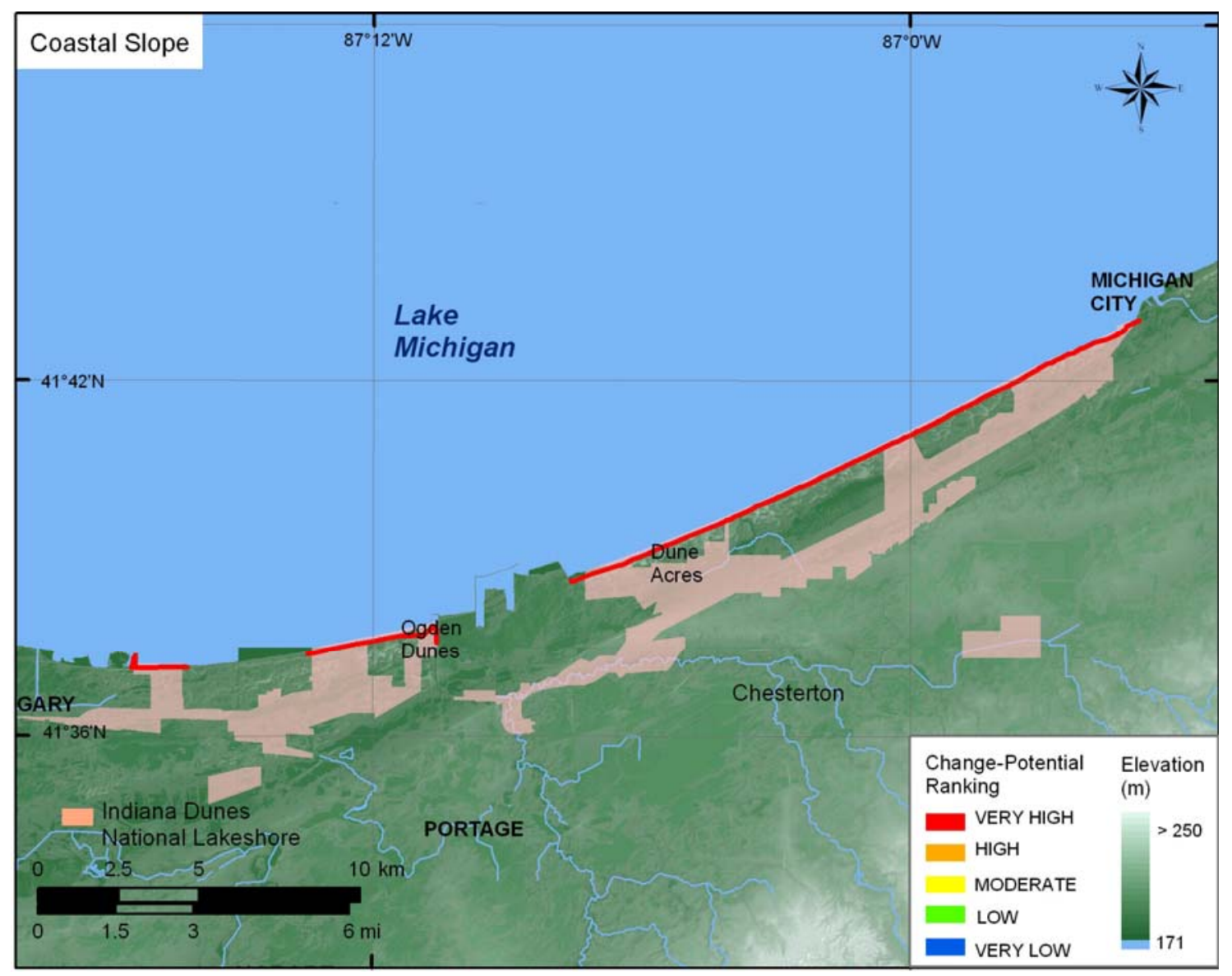

Figure 8B. Regional coastal slope for Indiana Dunes National Lakeshore. The colored shoreline represents the regional slope of the land, $5 \mathrm{~km}$ landward and lakeward of the shoreline. 


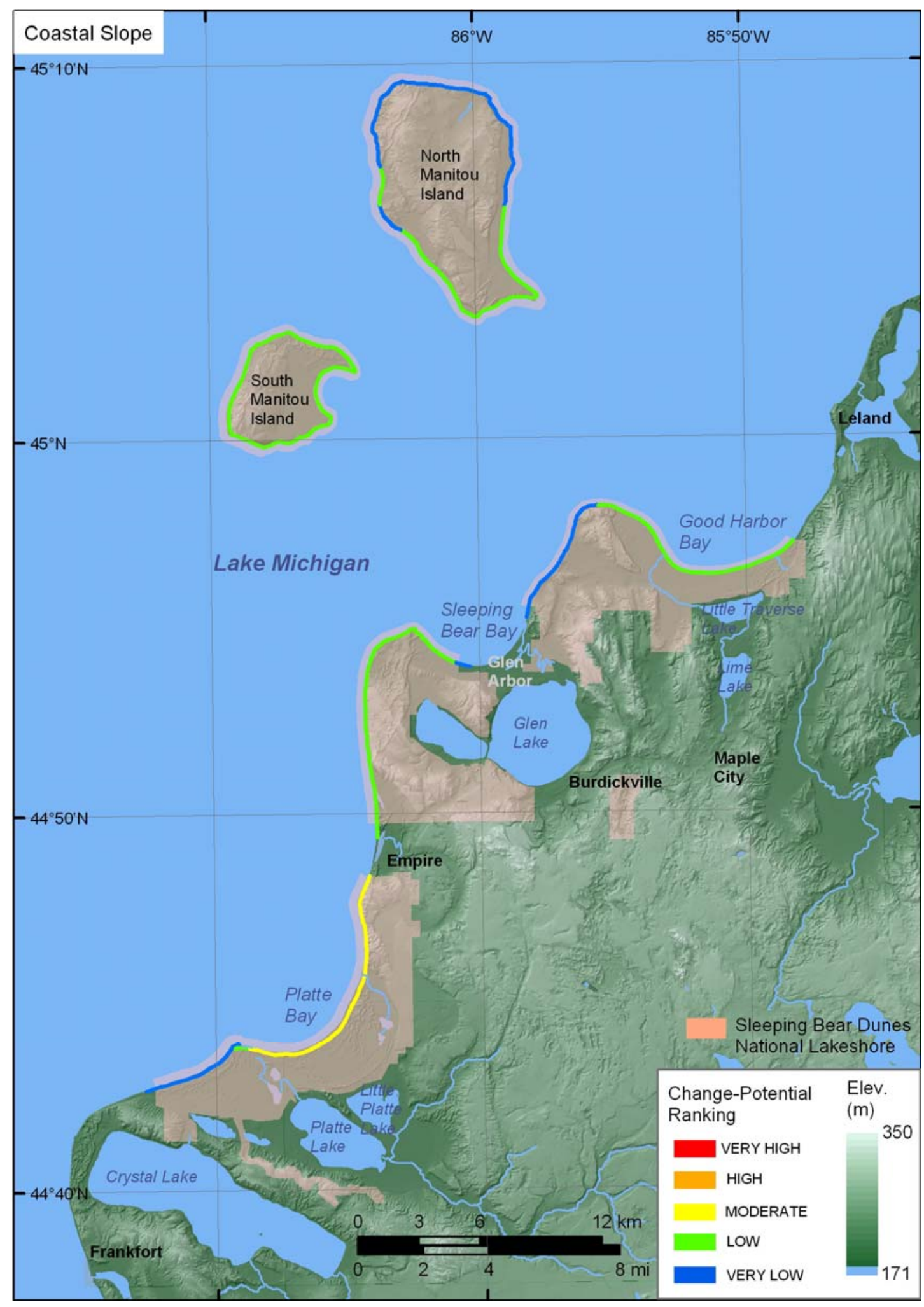

Figure 8C. Regional coastal slope for Sleeping Bear Dunes National Lakeshore. The colored shoreline represents the regional slope of the land, $5 \mathrm{~km}$ landward and lakeward of the shoreline. 


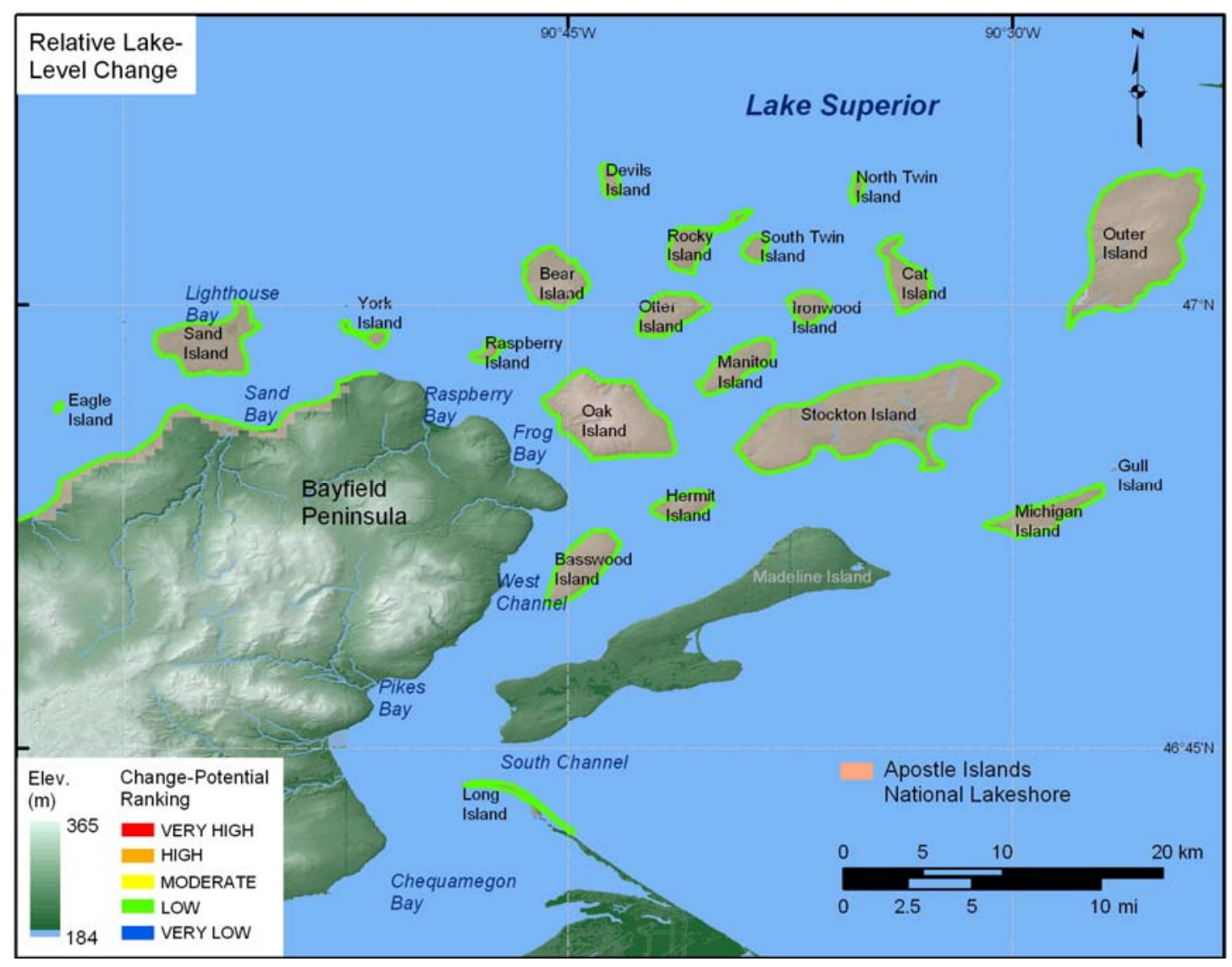

Figure 9A. Rate of relative lake-level change for Apostle Islands National Park. 


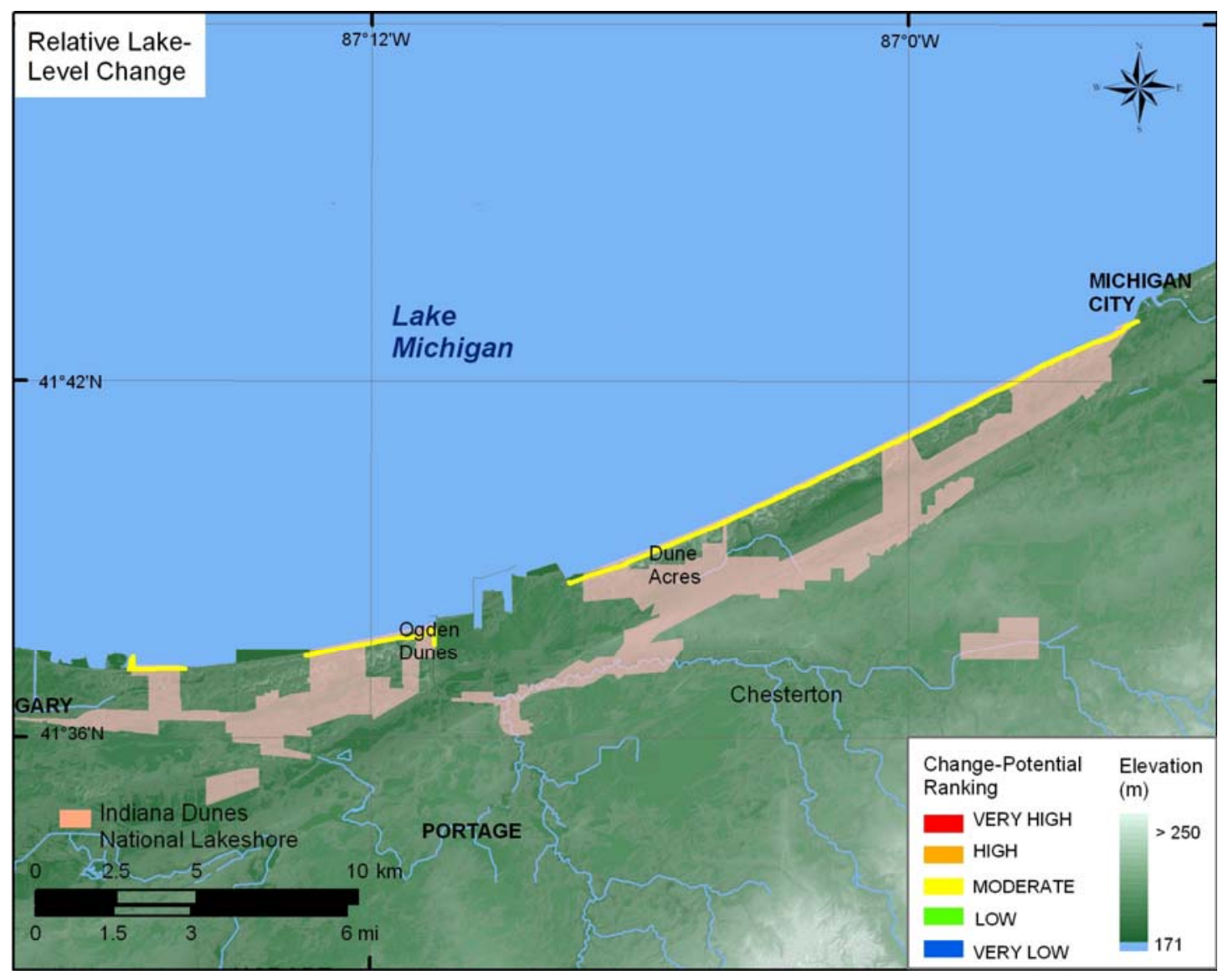

Figure 9B. Rate of relative lake-level change for Indiana Dunes National Park. 


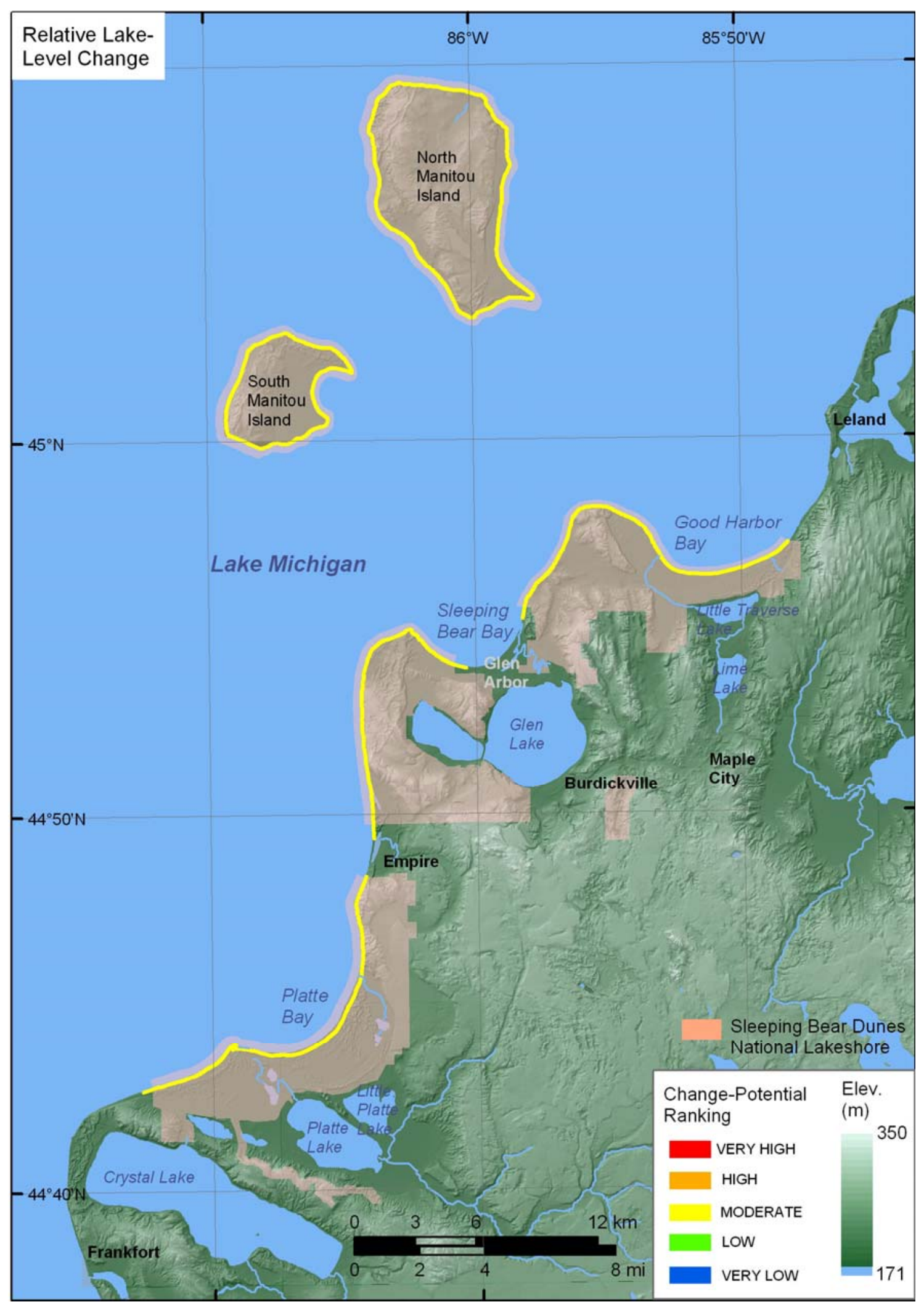

Figure 9C. Rate of relative lake-level change for Sleeping Bear Dunes National Park. 


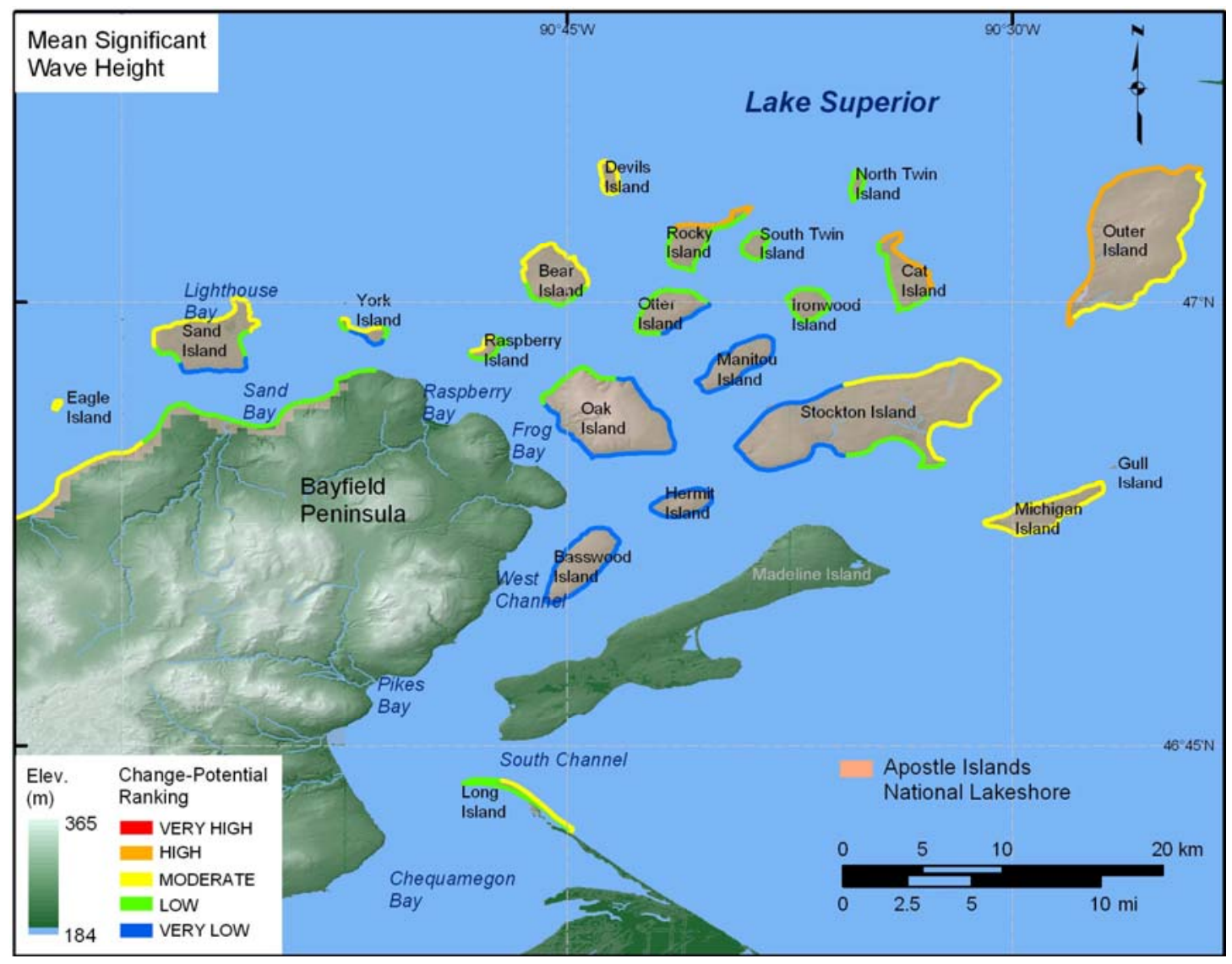

Figure 10A. Mean significant wave heights for Apostle Islands National Lakeshore. The colored shoreline represents the ranked mean significant heights within the park. 


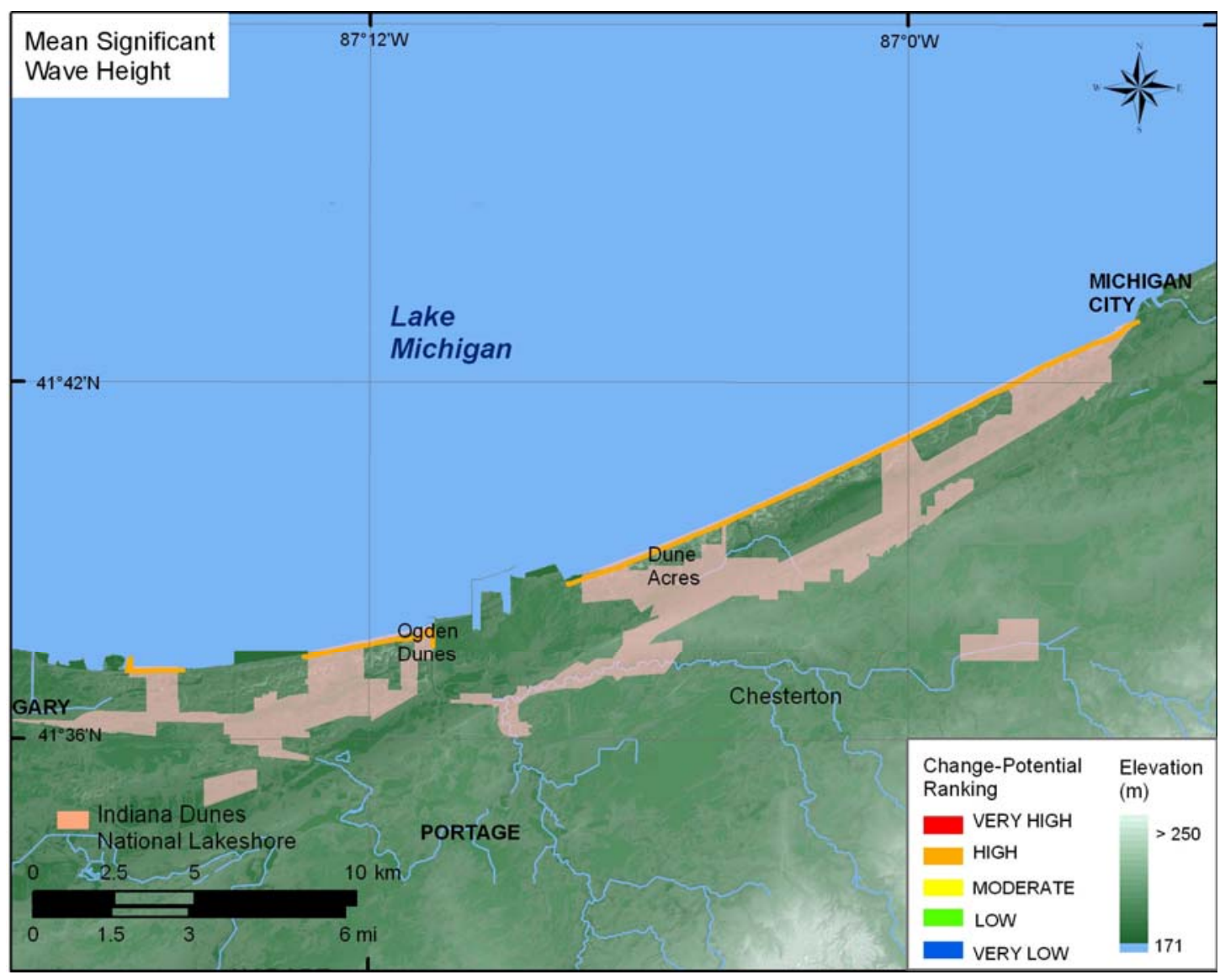

Figure 10B. Mean significant wave heights for Indiana Dunes National Lakeshore. The colored shoreline represents the ranked mean significant heights within the park. 


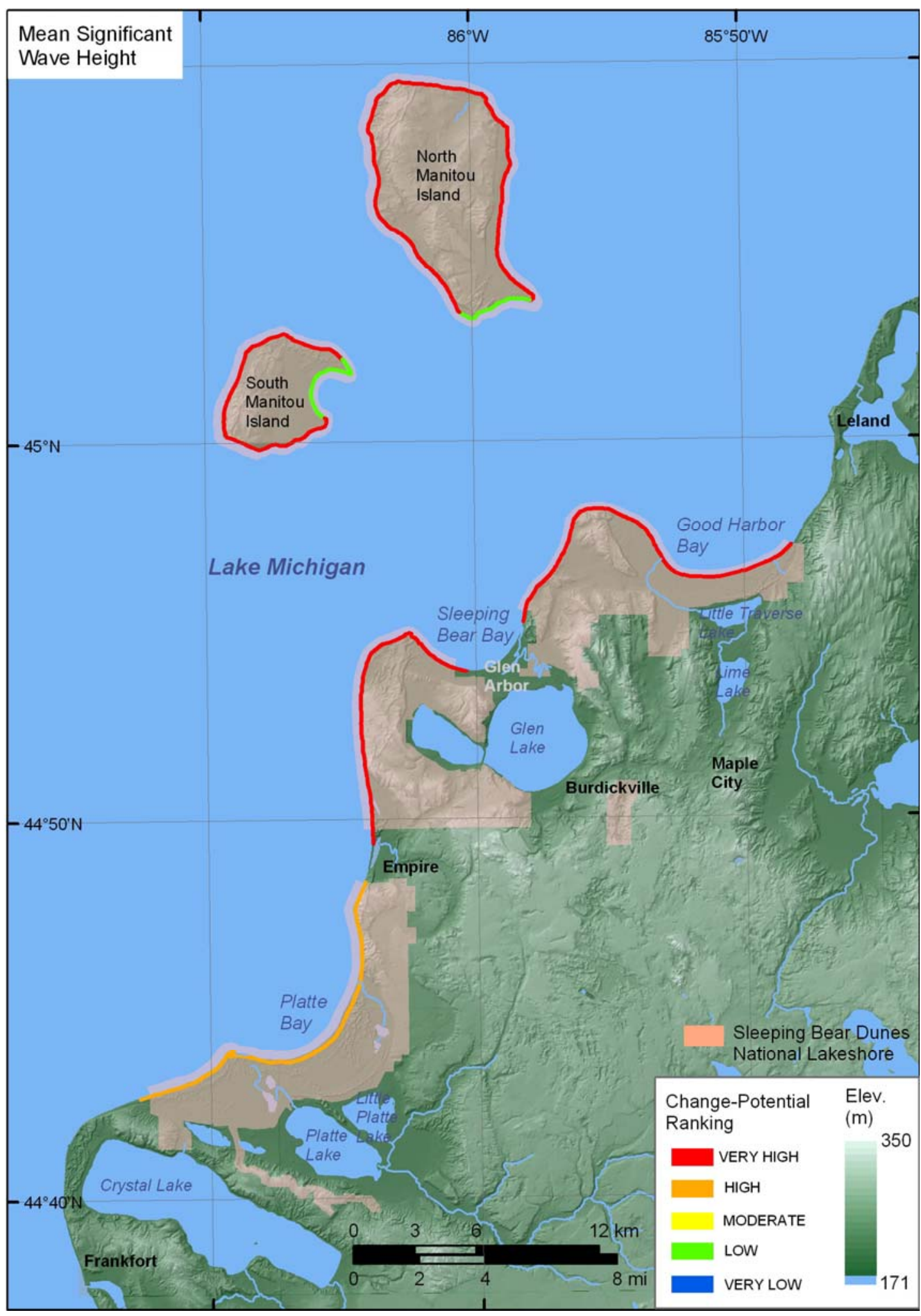

Figure 10C. Mean significant wave heights for Sleeping Bear Dunes National Lakeshore. The colored shoreline represents the ranked mean significant heights within the park. 


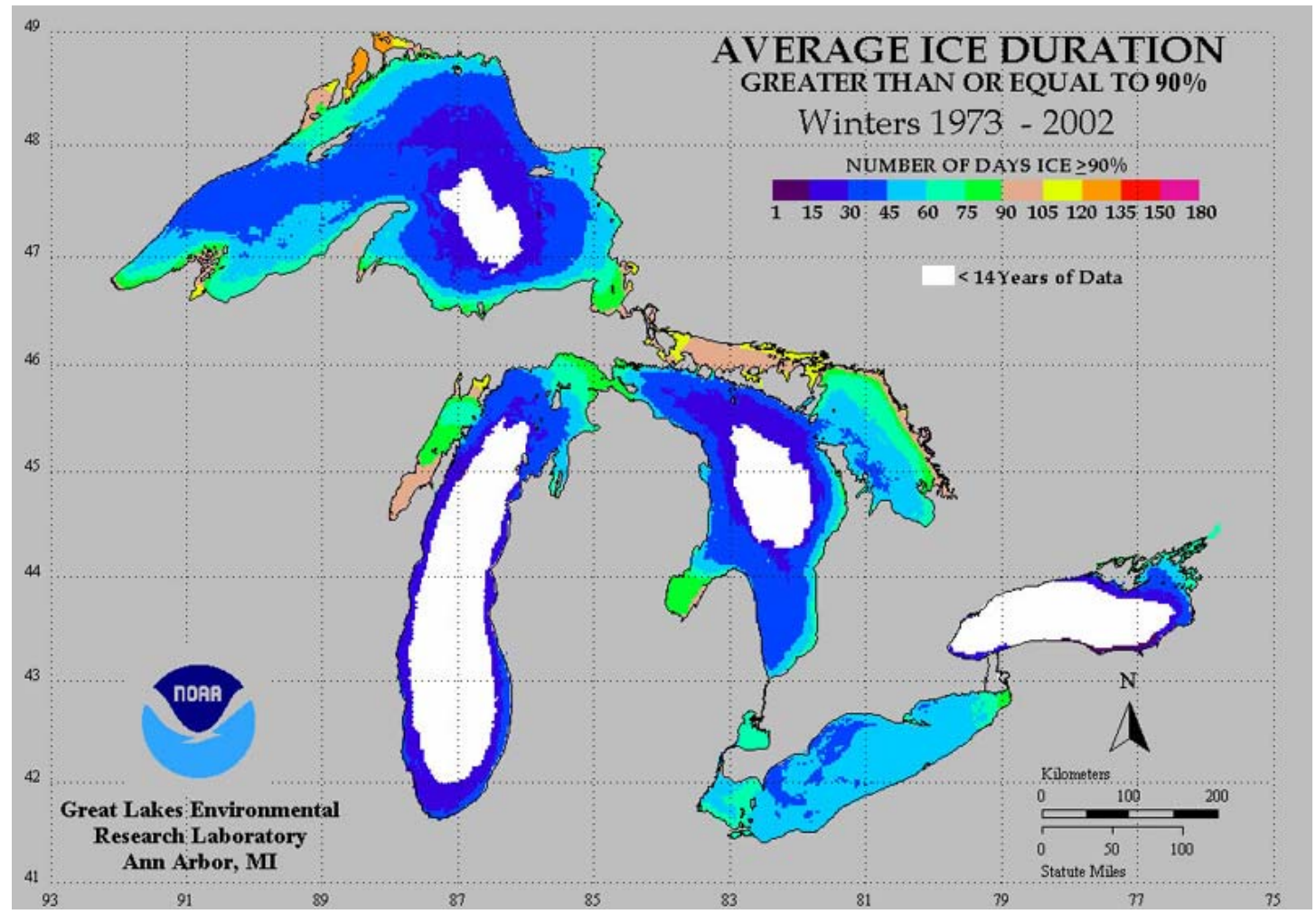

Figure 11. Mean Annual Ice Duration for the Great Lakes for Winters 19732002 (Assel, 2003). 


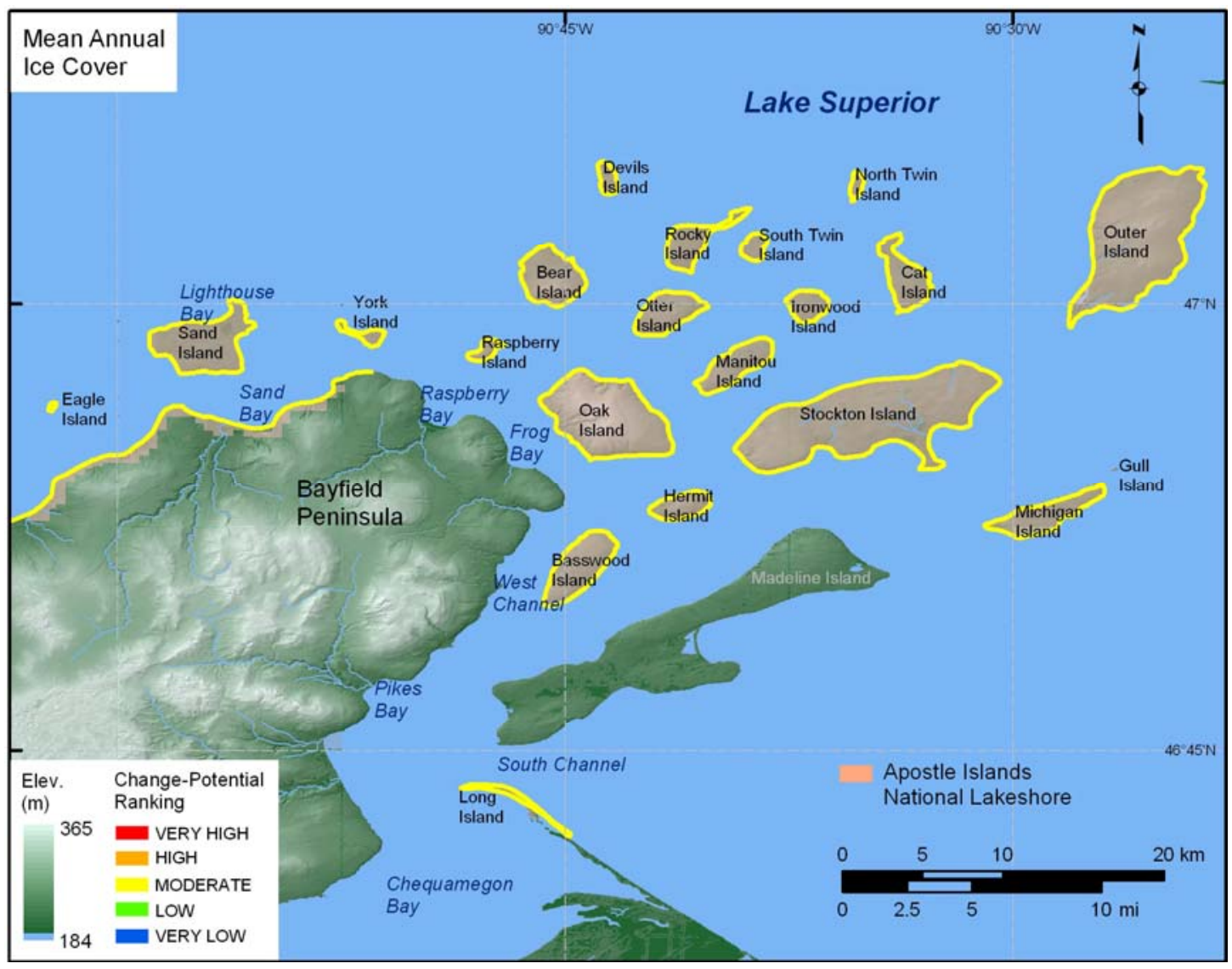

Figure 12A. Mean Annual Ice Cover for Apostle Islands National Lakeshore. 


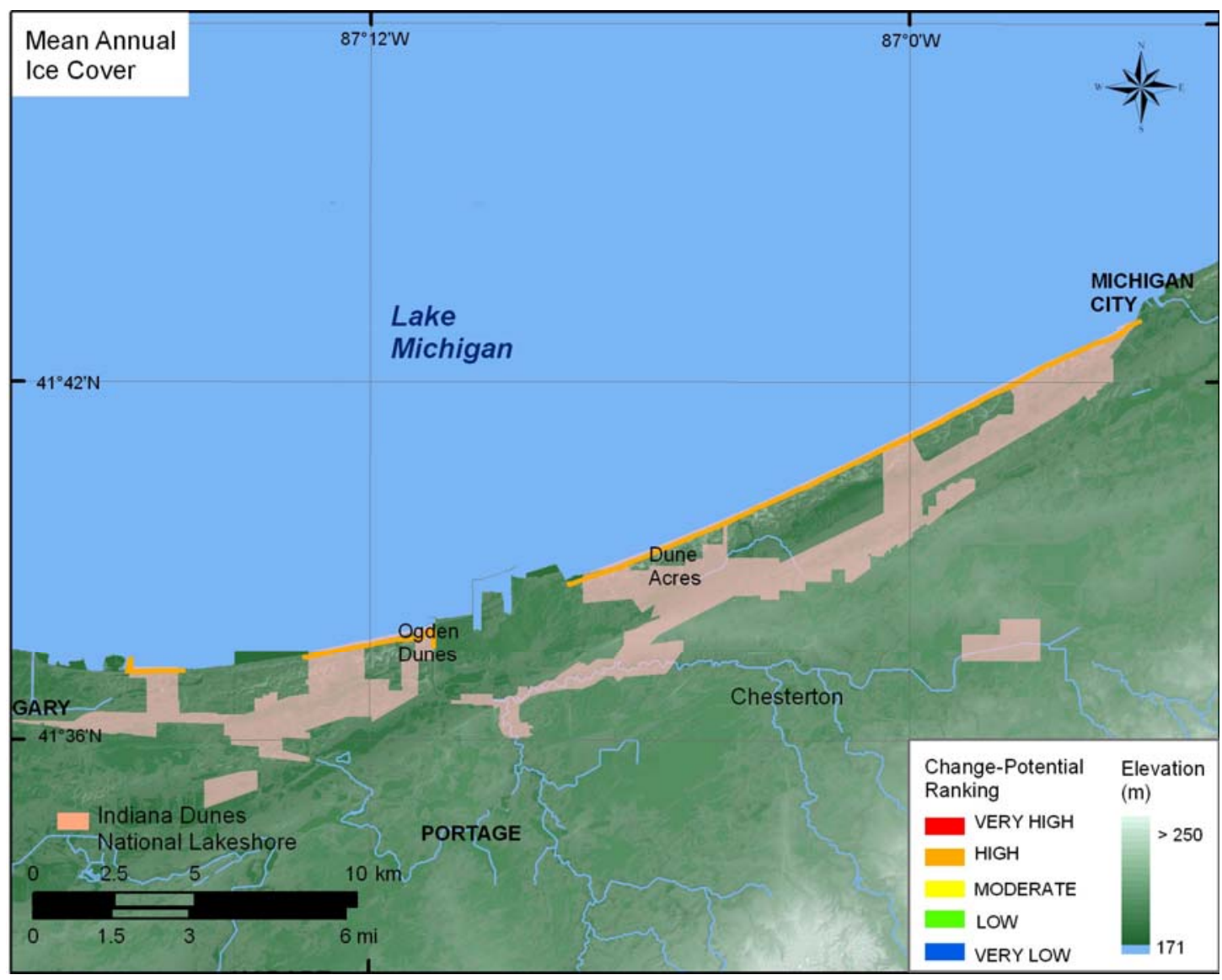

Figure 12B. Mean Annual Ice Cover for Indiana Dunes National Lakeshore. 


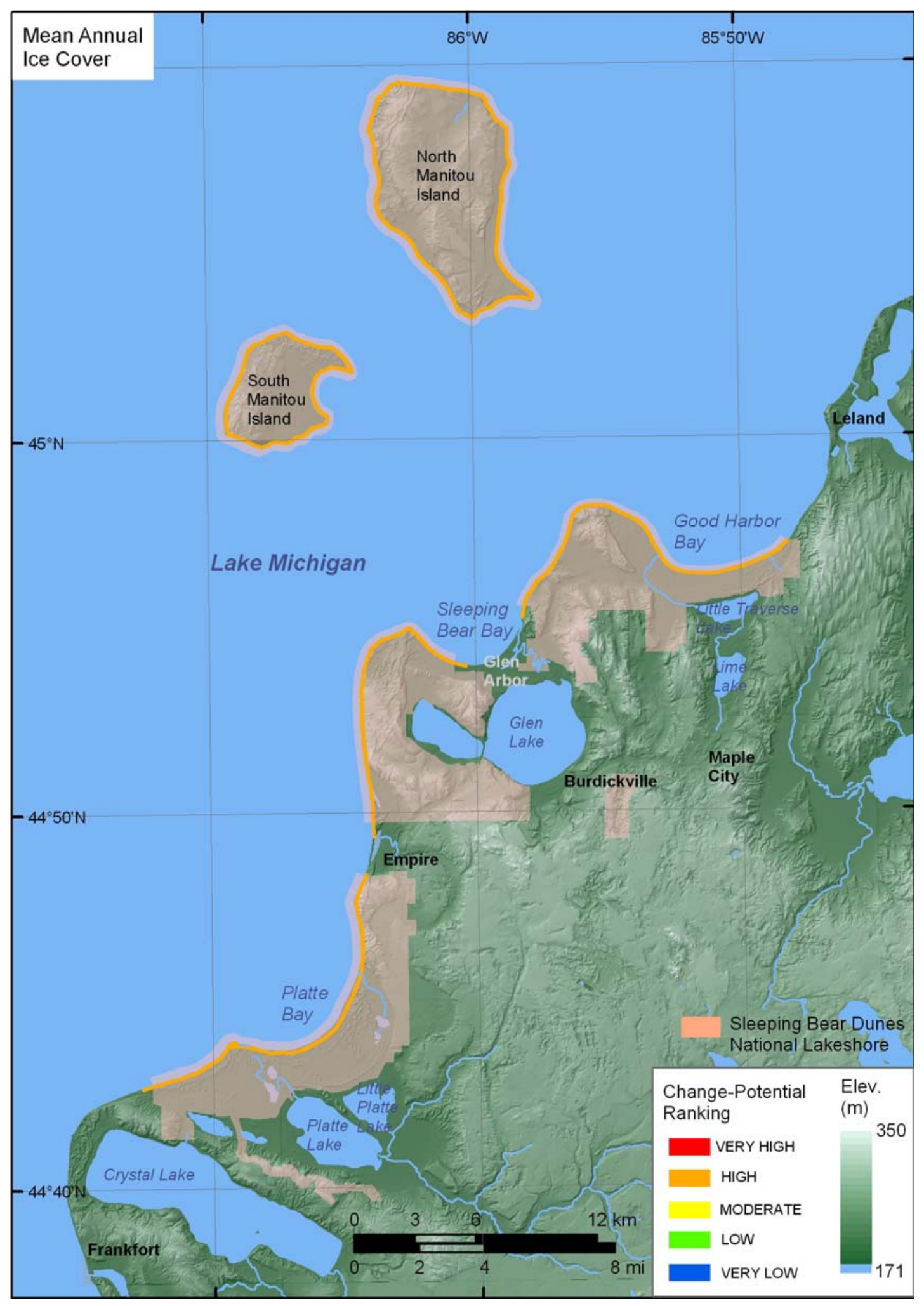

Figure 12C. Mean Annual Ice Cover for Sleeping Bear Dunes National Lakeshore. 


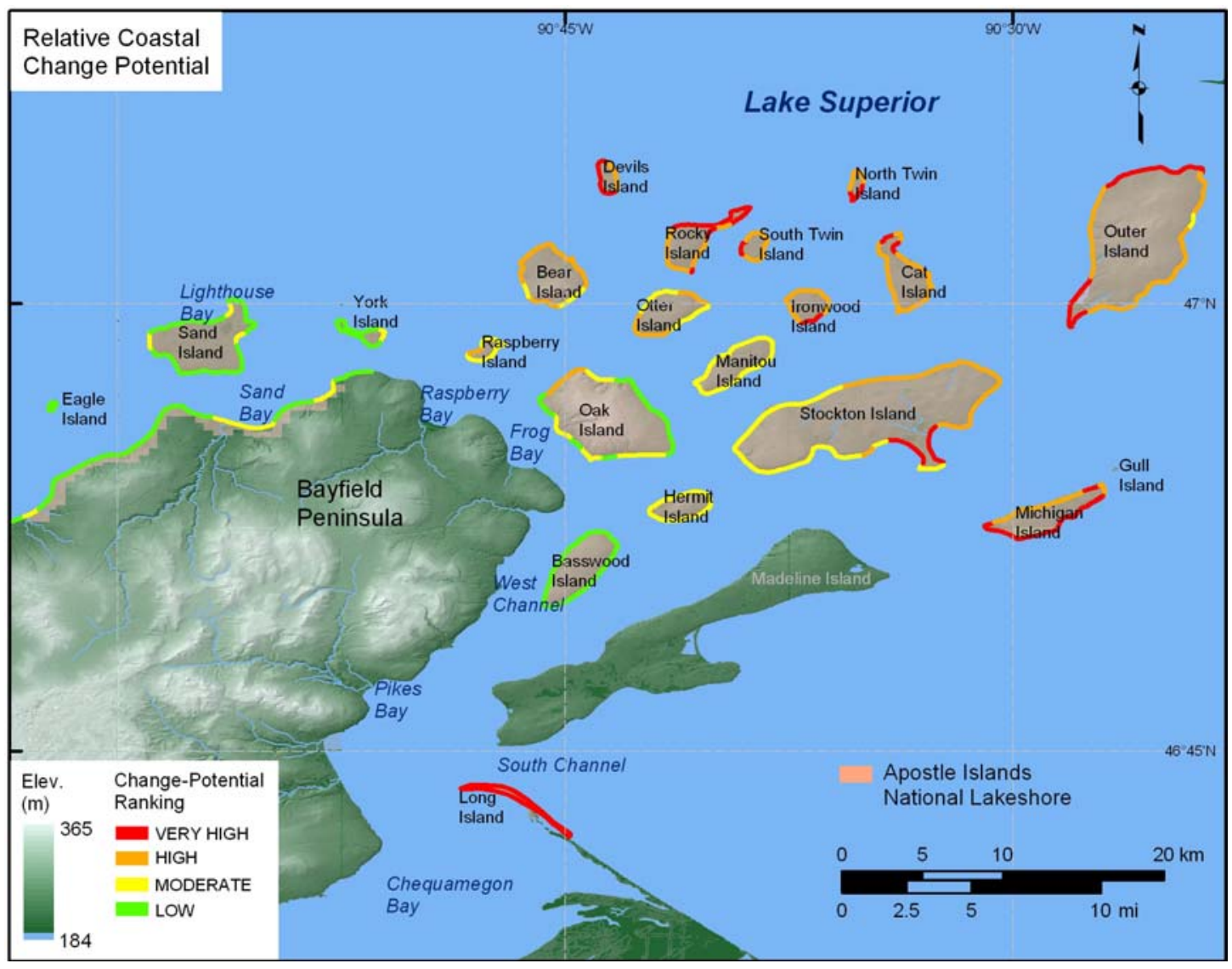

Figure 13A. Relative Coastal Change-potential for Apostle Islands National Lakeshore. The colored shoreline represents the relative coastal change-potential index (CPI) determined from six variables. The very high change-potential shoreline is located along sandy stretches where significant wave heights are highest. The low changepotential shoreline is located along bluffs where wave heights are low. 


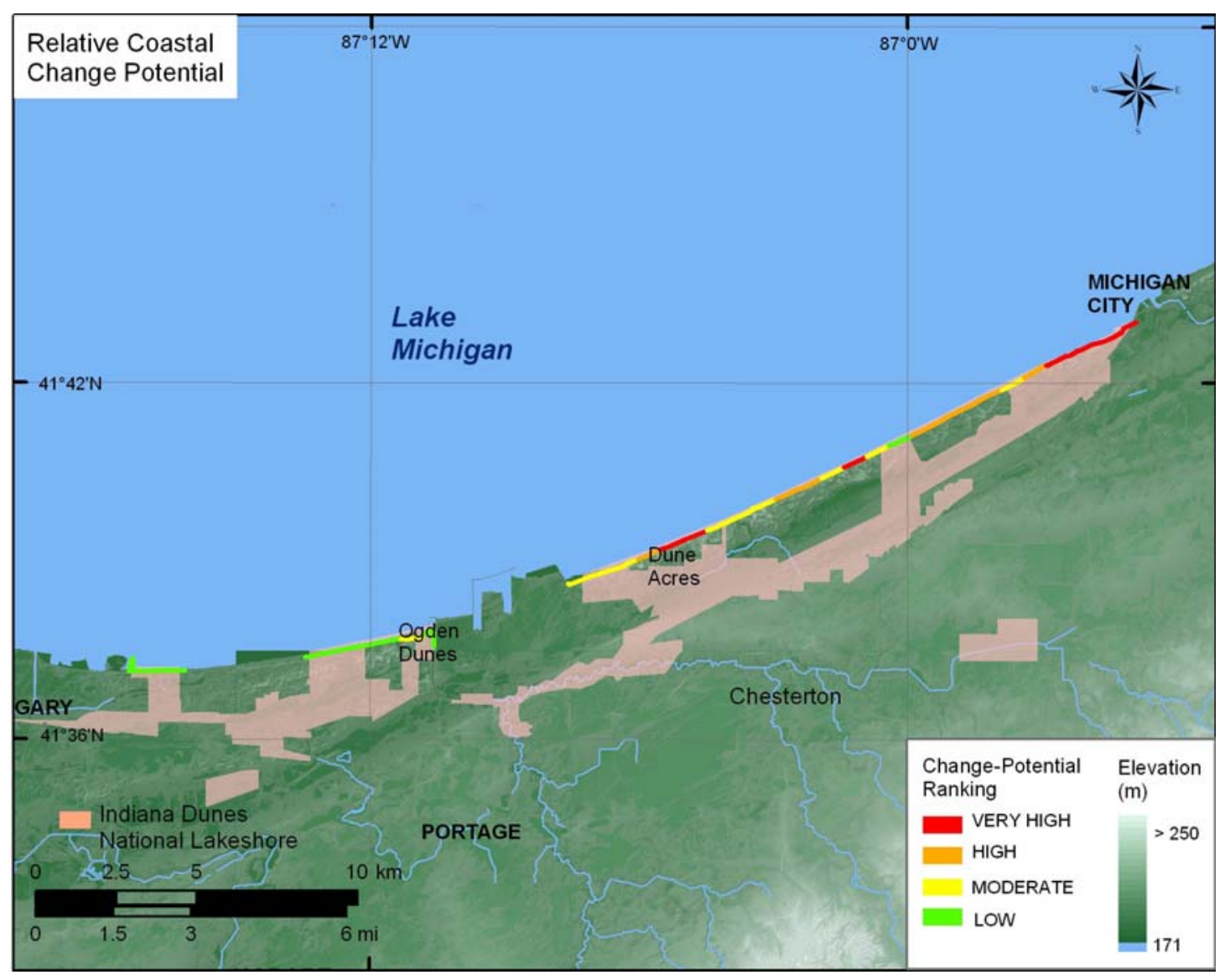

Figure 13B. Relative Coastal Change-potential for Indiana Dunes National Lakeshore. The colored shoreline represents the relative coastal change-potential index (CPI) determined from the six variables. The very high change-potential shoreline is located along sandy stretches of coast where shoreline recession rates are highest. The low change-potential shoreline is located along bluffs where shoreline recession is lower. 


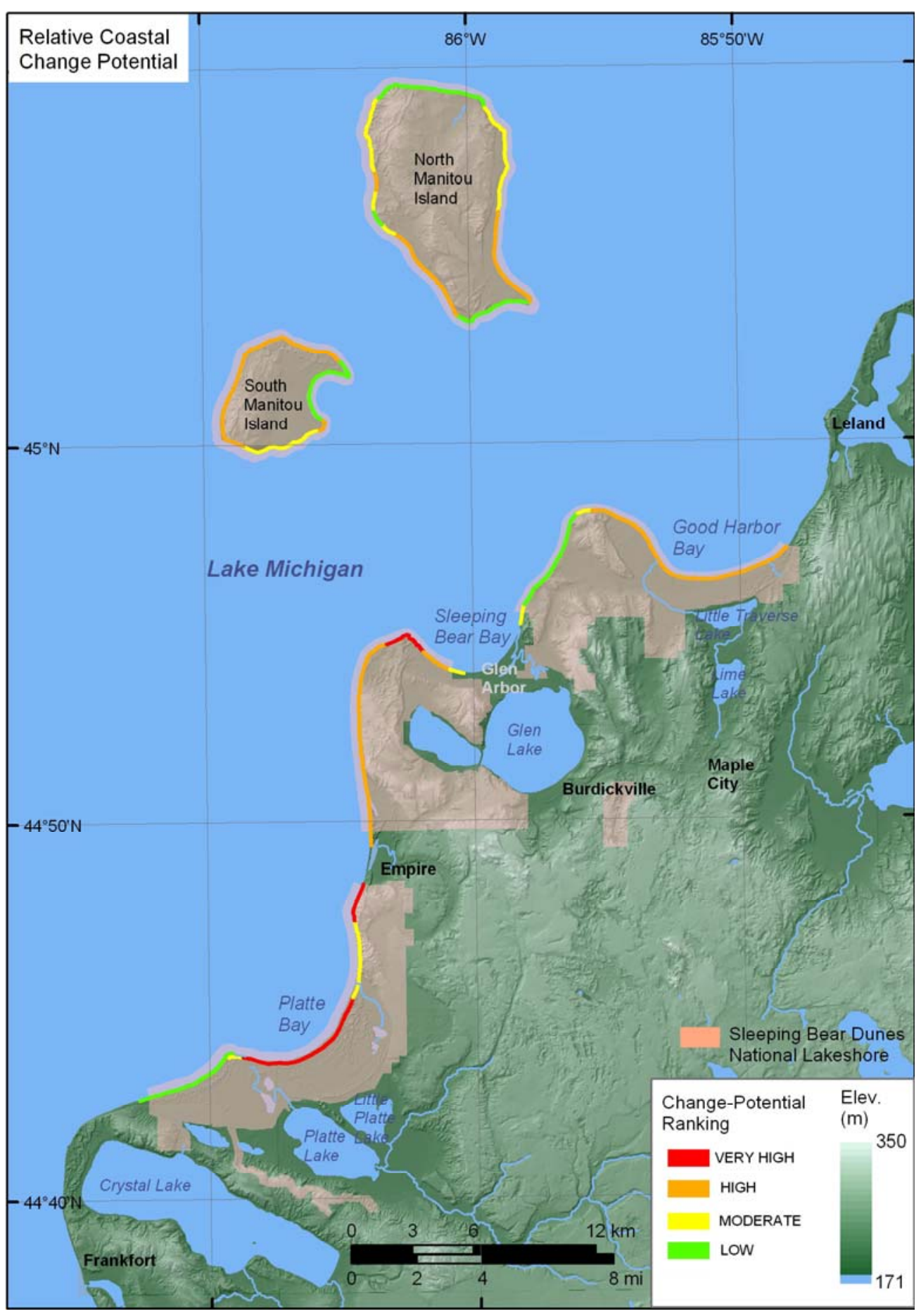

Figure 13C. Relative Coastal Change-potential for Sleeping Bear Dunes National Lakeshore. The colored shoreline represents the relative coastal change-potential index (CPI) determined from the six variables. The very high change-potential shoreline is located along sandy stretches of coast where regional coastal slope change-potential is high. The low changepotential shoreline is located along bluffs where coastal slope is steeper and wave heights are generally low. 


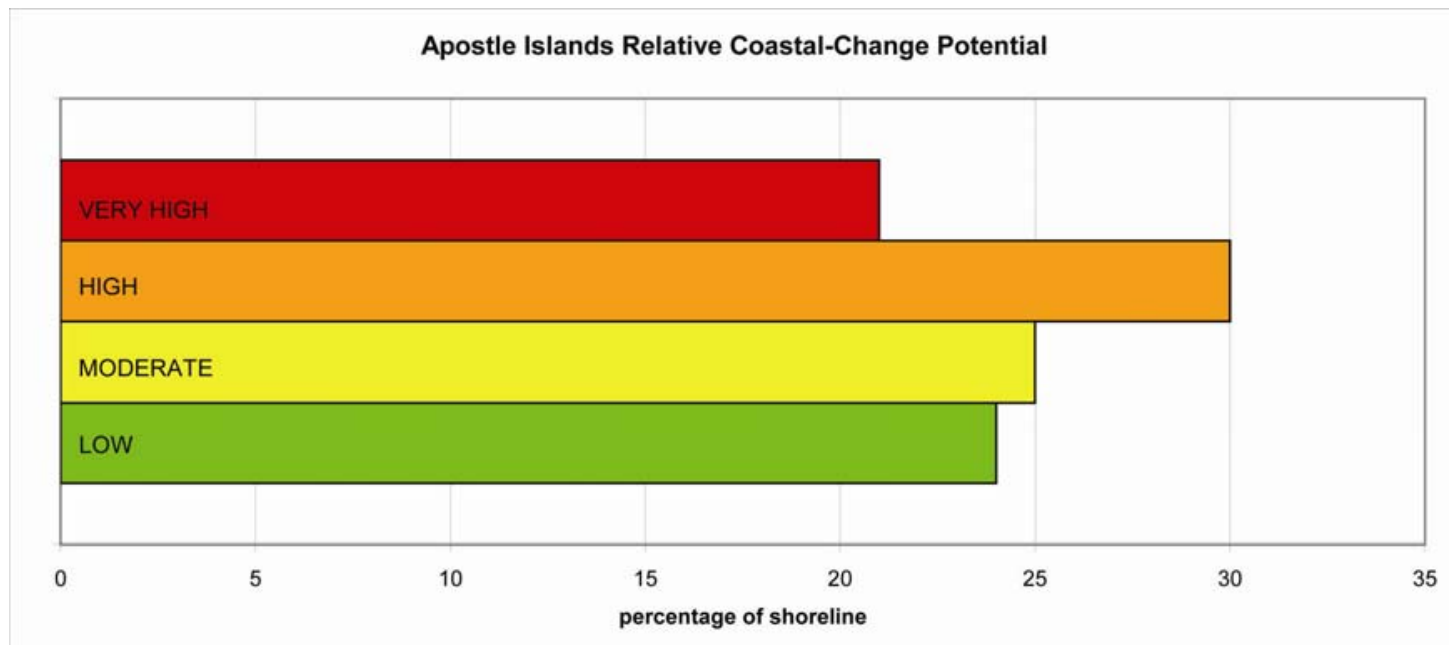

Figure 14A. Percentage of Apostle Islands NL shoreline in each CPI category. 


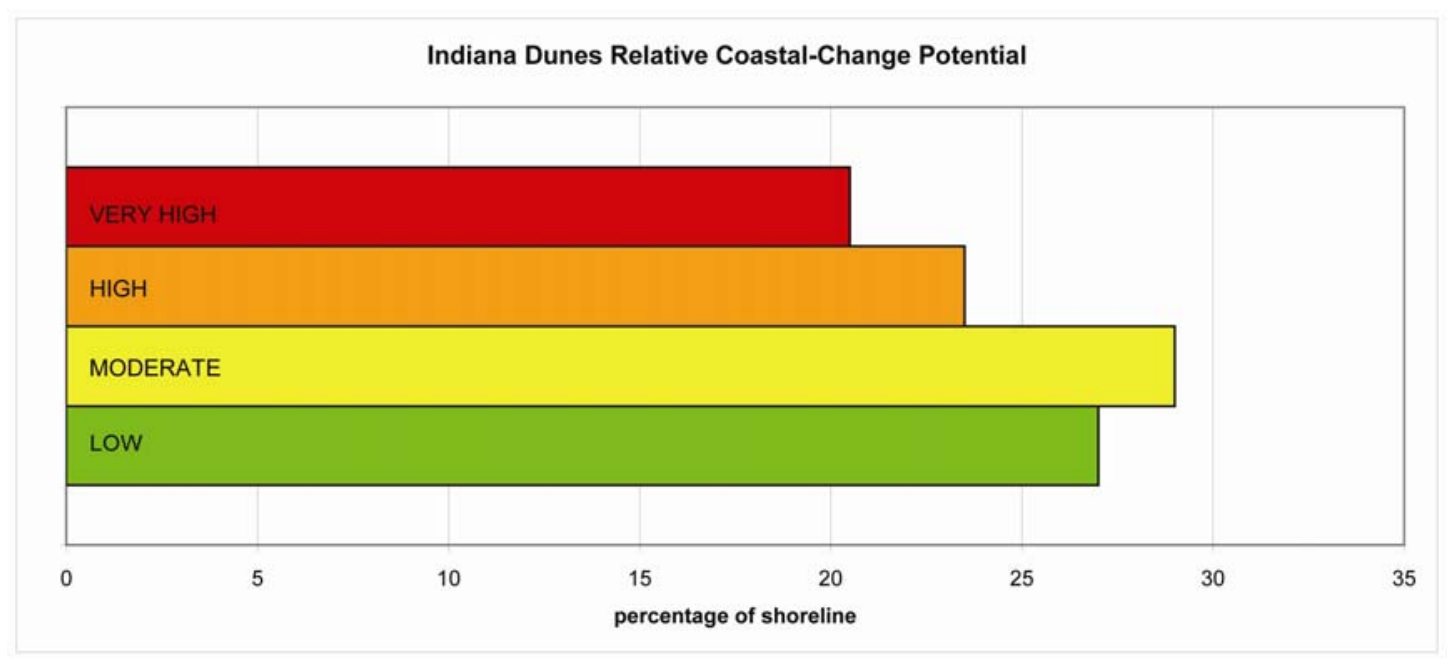

Figure 14B. Percentage of Indiana Dunes NL shoreline in each CPI category. 
Sleeping Bear Dunes Relative Coastal-Change Potential

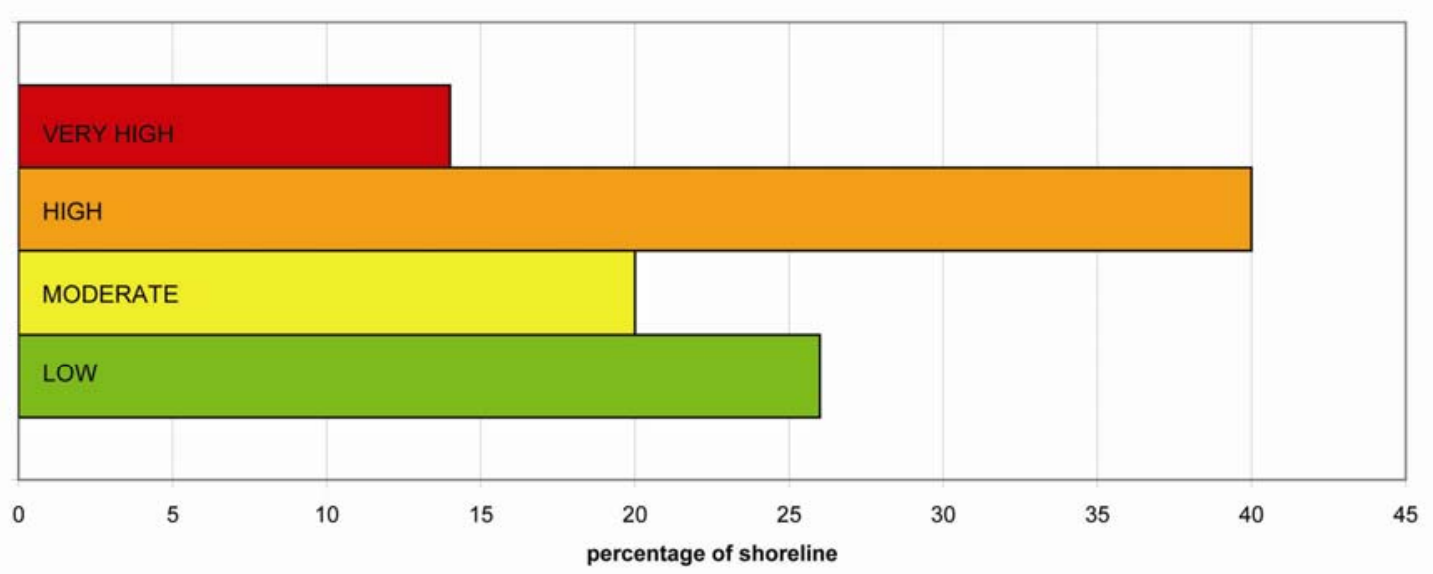

Figure 14C. Percentage of Sleeping Bear Dunes NL shoreline in each CPI category. 


\section{Tables}

Table 1. Ranges for Coastal Change Potential Ranking of Variables on the Great Lakes shores.

\begin{tabular}{|l|l|l|l|l|l||}
\hline \multicolumn{1}{|c|}{ Variables } & $\begin{array}{c}\text { Very } \\
\text { Low }\end{array}$ & \multicolumn{1}{|c|}{$\begin{array}{c}\text { Low } \\
\mathbf{2}\end{array}$} & $\begin{array}{c}\text { Moderate } \\
\mathbf{3}\end{array}$ & \multicolumn{1}{|c|}{$\begin{array}{c}\text { High } \\
\mathbf{4}\end{array}$} & \multicolumn{1}{|c|}{$\begin{array}{c}\text { Very High } \\
\mathbf{5}\end{array}$} \\
\hline \hline GEOMORPHOLOGY & $\begin{array}{l}\text { Rocky } \\
\text { cliffed } \\
\text { coasts, } \\
\text { Fjords }\end{array}$ & $\begin{array}{l}\text { Medium } \\
\text { cliffs, } \\
\text { Indented } \\
\text { coasts }\end{array}$ & $\begin{array}{l}\text { Low cliffs, } \\
\text { Glacial drift, } \\
\text { Alluvial } \\
\text { plains }\end{array}$ & $\begin{array}{l}\text { Cobble } \\
\text { Beaches, } \\
\text { Estuary, } \\
\text { Lagoon }\end{array}$ & $\begin{array}{l}\text { Barrier beaches, Sand } \\
\text { beaches, Salt marsh, Mud } \\
\text { flats, Deltas }\end{array}$ \\
\hline $\begin{array}{l}\text { SHORELINE CHANGE- } \\
\text { POTENTIAL (m/yr) }\end{array}$ & N/A & $0- \pm 1$ & $\pm 1- \pm 2$ & $> \pm 2$ & N/A \\
\hline COASTAL SLOPE $(\%)$ & $>1.20$ & $1.20-0.90$ & $0.90-0.60$ & $0.60-0.30$ & $<0.30$ \\
\hline $\begin{array}{l}\text { RELATIVE LAKE- } \\
\text { LEVEL CHANGE } \\
\text { (mm/yr) }\end{array}$ & 0 & $0.1-3$ & $3.1-6$ & $6.1-9$ & $>9.1$ \\
\hline $\begin{array}{l}\text { MEAN ANNUAL ICE } \\
\text { COVER (days) }\end{array}$ & $>135$ & $106-135$ & $61-105$ & $30-60$ & $<30$ \\
\hline $\begin{array}{l}\text { MEAN WAVE HEIGHT } \\
\text { (m) }\end{array}$ & $<0.55$ & $0.55-0.84$ & $0.85-1.04$ & $1.05-1.24$ & $>1.25$ \\
\hline
\end{tabular}


Table 2. Sources of Data

\begin{tabular}{|c|c|c|}
\hline Variables & Source & $\begin{array}{c}\text { URL } \\
\text { (Not all sources are downloadable) }\end{array}$ \\
\hline GEOMORPHOLOGY & $\begin{array}{l}\text { Aerial photography and surficial } \\
\text { geology maps from state GIS } \\
\text { organizations and NPS Natural } \\
\text { Resource and GIS Programs }\end{array}$ & $\begin{array}{l}\text { http://www.michigan.gov/cgi } \\
\text { http://www.state.in.us/ingisi/ } \\
\text { http://science.nature.nps.gov/nrdata/index.cfm }\end{array}$ \\
\hline $\begin{array}{l}\text { SHORELINE } \\
\text { EROSION/ACCRETION } \\
(\mathrm{m} / \mathrm{yr})\end{array}$ & $\begin{array}{l}\text { United States Great Lakes shoreline } \\
\text { recession rate data (final report) } \\
\text { (Stewart, 1994) }\end{array}$ & http://www.cjscons.com/downloads/RecREPORT1.pdf \\
\hline COASTAL SLOPE (\%) & $\begin{array}{l}\text { NOAA/NGDC Global Land One-km } \\
\text { base elevation project (globe) }\end{array}$ & http://www.ngdc.noaa.gov/mgg/topo/globe.html \\
\hline $\begin{array}{l}\text { RELATIVE SEA-LEVEL } \\
\text { CHANGE (mm/yr) }\end{array}$ & $\begin{array}{l}\text { Preparing for a Changing Climate: } \\
\text { Great Lakes Overview (Great Lakes } \\
\text { Regional Assessment Group, 2000) and } \\
\text { NOAA's Great Lakes Environmental } \\
\text { Research Laboratory (GLERL, 2006) }\end{array}$ & $\begin{array}{l}\text { http://www.geo.msu.edu/glra/assessment/assessment.html } \\
\text { http://www.glerl.noaa.gov/data/now/wlevels/levels.html }\end{array}$ \\
\hline $\begin{array}{l}\text { MEAN WAVE HEIGHT } \\
(\mathrm{m})\end{array}$ & $\begin{array}{l}\text { Great Lakes WIS Data and National } \\
\text { Data Buoy Center }\end{array}$ & $\begin{array}{l}\text { http://frf.usace.army.mil/wis/wis_main.html } \\
\text { http://lakeboard.ndbc.noaa.gov/ }\end{array}$ \\
\hline $\begin{array}{l}\text { MEAN ANNUAL ICE } \\
\text { COVER (DAYS) }\end{array}$ & $\begin{array}{l}\text { NOAA GLERL report: An Electronic } \\
\text { Atlas of Great Lakes Ice Cover Winters: } \\
1973 \text { - } 2002 \text { (Assel, 2003) }\end{array}$ & http://www.glerl.noaa.gov/data/ice/atlas/ \\
\hline
\end{tabular}

